\title{
High Tibial Open-Wedge Osteotomy - New Techniques and Early Results
}

\author{
Werner Kolb ${ }^{1}$, Hanno Guhlmann², Christoph Windisch ${ }^{2}$ and Klaus Kolb 3 \\ ${ }^{1}$ Department of Trauma and Orthopaedic Surgery, Bethesda Hospital, Stuttgart \\ 2Department of Trauma Surgery, Friedrich-Schiller-University, Jena \\ ${ }^{3}$ Department of Trauma Surgery, Klinikum am Steinenberg, Reutlingen,
}

Germany

\section{Introduction}

High tibial osteotomy was first described by Langenbeck in 1854 (Langenbeck 1854). It is an efficient method to treat unicondylar osteoarthrosis. High tibial osteotomy allows one to interrupt the circular reasoning of unicondylar osteoarthrosis (Fig. 1) (Jakob \& Jacobi, 2004).

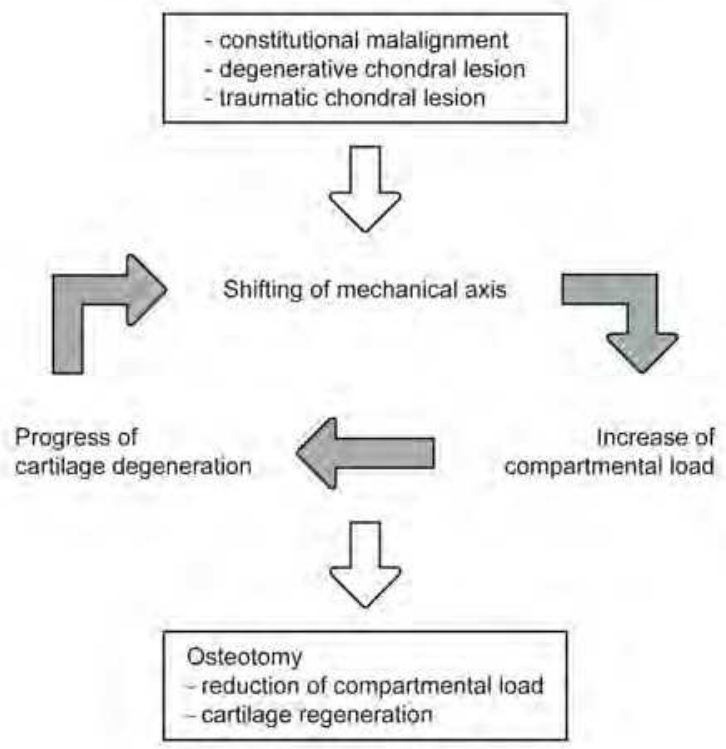

Fig. 1. The circular reasoning of unicondylar arthrosis (from Jakob \& Jacobi, 2004).

Following high tibial osteotomy, osteosclerosis in the medial compartment of the arthritic knee is significantly reduced, and the degenerated portions of the articular surface are completely covered by a fibrocartilagenous layer (Akamatsu et al., 1997; Fujisawa et al., 1979; Koshino, \& Tsuchiya, 1979; Koshino, 2010; Odenbring et al. 1992; Takahashi et al. 2002-2003). 
An open-wedge high tibial osteotomy proximal to the tibial tuberosity was first described by Debeyre and Patte in 1951 (Debeyre \& Patte, 1962). A disadvantage of this method is the need for bone grafts and the resulting risk of donor-site morbidity (Becker et al., 2011). Thus, because of its inherent stability, closed-wedge osteotomy has become the treatment of choice for unicompartmental osteoarthritis (Coventry, 1965).

Unicompartmental (or total knee) arthroplasty has been the treatment of choice because osteotomy is considered a demanding procedure with an unpredictable outcome and is associated with significant complications. The biological internal fixation of fractures using the indirect reduction technique could improve the outcome in treating fractures (Mast et al., 1989). The "minimally invasive plate osteosynthesis (MIPO) technique" further improves the results of plate osteosynthesis . Locked-plate fixators significantly improve the stability of plate osteosynthesis. The combination of locked-plate fixators and the MIPO technique makes it possible to perform plateosteosynthesis without the need for bone grafts. Menisceal and chondral lesions both as ligament instabilities have an increased risk for osteoarthritis (Hofmann et al., 2009). In young patients with a varus malalignment, the treatment of menisceal or chondral lesions both as ligament instabilites can be combined with a high tibial osteotomy (Noyes et al., 1993; Imhoff et al., 2004). The combination of varus malalignment with chronic posterolateral instability was defined as triple varus by Noyes and Simon (Noyes \& Simon, 1994).

The keys to a successful osteotomy are basic biomechanics, careful patient selection, and precise planning combined with a skilful surgical technique and stable osteosynthesis for early mobilisation (Hanssen, 2001; Hofmann et al., 2009). Remarkably, the patient selection process and the specific indications for osteotomy are more standardised than the various preoperative planning methods and operative techniques currently being used (Hanssen, 2001). Given the positive long-term outcome of osteotomy when strict selection criteria are implemented and the compliance with a rigorous technique, it appears that these procedures have their place in the treatment of the early stages of gonarthrosis that arise from axial deviation (Poilvache, 2001). Careful planning of the axis of correction and the osteotomy, the degree of correction and the implant allow one to avoid complications such as nerve injury, instability and pseudoarthrosis (Lichte et al. 2010).

Periarticular corrective osteotomies have grown in importance since the advent of locking compression plates (Köck et al., 2011)

New planning methods as well as new techniques for open-wedge high tibial osteotomies and custom-designed internal fixators have improved upon the early results and have led to a trend towards high tibial open-wedge osteotomy. Medial open-wedge high tibial osteotomy secured by a TomoFix plate (Synthes, West Chester, Pennsylvania) provides stability that is equal to the lateral closing-wedge technique (Luites et al., 2009). The TomoFix plate is an anatomically pre-contoured locked plate for the medial aspect of the tibia and is inserted into a subcutaneous tunnel with minimal bone exposure (Kolb et al., 2009).

The aim of this report is to (1) describe new planning methods and (2) describe new techniques for open-wedge high tibial osteotomy.

\section{Indication}

The typical indication for deformity correction is a combination of morphological, functional and radiographic results in terms of both the personal situation of the patient (e.g., expectation, compliance, general factors such as smoking, peripheral vascular 
status, nutritional status, comorbidities such as diabetes, occupational situation and sports activities) and the length of rehabilitation (Hofmann et al., 2009; Tunggal et al., 2010). The primary indications are active patients who are between 40 and 60 years of age with varus malalignment of the limb with no radiographic evidence of subluxation, no patellofemoral symptoms, isolated medial activity-related joint line pain, full extension, and a knee arc of motion that is $>100^{\circ}$. In reality, however, there are many other patients who would benefit from osteotomy but fall short of these idealised criteria (Hanssen \& Chao, 1994) (Table 1).

\begin{tabular}{|c|c|c|}
\hline Absolute Indications & Relative Indications & Absolute Contraindications \\
\hline Patients $40-60$ years of age & $\begin{array}{l}\text { Patients }>60 \text { or }<40 \text { years } \\
\text { of age }\end{array}$ & Open growth plates \\
\hline $\begin{array}{l}\text { Varus malalignment of the } \\
\operatorname{limb}<15^{\circ}\end{array}$ & $\begin{array}{l}\text { Varus malalignment }>15^{\circ} \\
\text { (sometimes double } \\
\text { osteotomy) }\end{array}$ & Rheumatoid arthritis \\
\hline $\begin{array}{l}\text { No patellofemoral } \\
\text { symptoms }\end{array}$ & $\begin{array}{l}\text { Moderate patellofemoral } \\
\text { symptoms }\end{array}$ & $\begin{array}{l}\text { Severe patellofemoral } \\
\text { symptoms }\end{array}$ \\
\hline $\begin{array}{l}\text { Isolated medial activity- } \\
\text { related joint line pain }\end{array}$ & & Lateral joint line pain \\
\hline Full extension & Flexion contracture $>15^{\circ}$ & Flexion contracture $>25^{\circ}$ \\
\hline Range of motion $>100^{\circ}$ & Range of motion $>90^{\circ}$ & Range of motion $<75^{\circ}$ \\
\hline Medial soft tissue coverage & Previous infection & Inflammatory disease \\
\hline Stable knee & $\begin{array}{l}\text { ACL, PCL or PLC } \\
\text { insufficiency }\end{array}$ & Mediolateral insufficiency \\
\hline No patellofemoral arthrosis & $\begin{array}{l}\text { Patellofemoral arthrosis } \\
\text { grade II - III* }\end{array}$ & $\begin{array}{l}\text { Patellofemoral arthrosis } \\
\text { grade IV-V* }\end{array}$ \\
\hline Non-smoker & $\begin{array}{l}\text { Smoker }(<15 \\
\text { cigarettes/day) }\end{array}$ & Smoker ( $>15$ cigarettes/day) \\
\hline $\mathrm{BMI}<30$ & BMI 30-40 & $\mathrm{BMI}>40$ \\
\hline $\begin{array}{l}\text { High-demand activity but } \\
\text { no running or jumping }\end{array}$ & $\begin{array}{l}\text { Wish to continue all } \\
\text { sports }\end{array}$ & Severe osteoporosis \\
\hline $\begin{array}{l}\text { Metaphyseal tibial varus } \\
\left(\text { TBVA }+>5^{\circ}\right)\end{array}$ & $\begin{array}{l}\text { Metaphyseal femoral } \\
\text { varus and tibial valgus }\end{array}$ & Extraarticular deformity \\
\hline $\begin{array}{l}\text { Normal lateral component, } \\
\text { arthrosis grade I-III* } \\
\text { medial component }\end{array}$ & $\begin{array}{l}\text { Arthrosis grade } \mathrm{IV}^{*} \\
\text { medial }\end{array}$ & $\begin{array}{l}\text { Lateral gonarthrosis, } \\
\text { Arthrosis grade } \mathrm{V}^{*} \text { medial }\end{array}$ \\
\hline No meniscectomy & $\begin{array}{l}\text { Partial medial } \\
\text { meniscectomy }\end{array}$ & Lateral meniscectomy \\
\hline \multirow[t]{2}{*}{ No cupula } & Osteochondritis dissecans & $\begin{array}{l}\text { Bad peripheral vascular } \\
\text { status (no foot pulse) }\end{array}$ \\
\hline & Condylar osteonecrosis & Bone healing disorders \\
\hline
\end{tabular}

*Ahlbäck Grading System for Degenerative Arthritis

+ tibial bone varus angle

Table 1. Ideal and possible patients for high tibial osteotomy and patients not suited for the procedure, modified from the International Society of Arthroscopy, Knee Surgery and Orthopaedic Sports Medicine (Brinkman et al., 2008; Frey et al., 2008; Hofmann et al., 2009; Kolb et al., 2009; Rand \& Neyret, 2005; Song et al., 2010) 


\section{Preoperative evaluation}

A preoperative clinical evaluation of the knee and adjacent joints is mandatory. The gait pattern of the patient, including additional varus, must be assessed (Müller, 2001). Limited mobility of the hip-, especially its rotation, -may influence both the gait pattern and dynamic load (Müller, 2001). A varus knee with internal rotation requires more valgus correction than in cases in which the foot is in its normal position (Müller, 2001). A preoperative gait analysis should become part of the routine preoperative patient assessment (Lind et al., 2011). High tibial osteotomy can reduce significantly the external adduction moment (Bhatnagar \& Jenkyn, 2010). According to the magnitude of the knee-adduction moment, (Prodomos et al., 1985) classified patients into low and high adduction moment groups, and patients with a low preoperative adduction moment had substantially better clinical results than did patients with high adduction moments. The dynamic situation may therefore be an important consideration in helping to explain certain failures or recurrences despite a good initial correction, as the static alignment of the knee cannot account for dynamic loading (Tunggal et al., 2010).

Radiographic assessment includes standard knee radiographs, full-length A-P view standing radiographs with the patella facing directly anterior with the patient standing on both legs, a lateral view, a flexed weightbearing tunnel view (Rosenberg's view) and skyline views of the patella with both knees in $30^{\circ}$ flexion (Merchant's view, Table 2). Patients with a positive varus stress test, increased varus during thrust, increased tibial external rotation at $30^{\circ}$ of flexion, or varus recurvatum during standing or walking should receive stress radiographs (Dugdale et al., 1992). If the radiographs are positive, the patient should receive supine full-length A-P radiographs of both legs to evaluate their true alignment (Noyes et al., 2000). The routine use of magnetic resonance imaging (MRI) to evaluate and manage meniscal tears, cartilage lesions or ligament injuries in patients with osteoarthritis of the knee is recommended (Bhattacharyya et al., 2003; Jakob \& Jacob, 2004; Englund et al., 2008). Bone marrow oedema in MRI is a potent risk factor for structural deterioration in knee osteoarthritis, and its relation to progression is explained in part by its association with limb alignment (Felson et al., 2003). Preoperative planning of the osteotomy using the MRI data is not recommended, as full-length views of the leg are not possible.

\begin{tabular}{|l|l|}
\hline Standard radiograph & Purpose \\
\hline $\begin{array}{l}\text { Full-length double stance A-P-radiograph (Moreland et } \\
\text { al., 1987) }\end{array}$ & To evaluate the femorotibial alignment \\
\hline $\begin{array}{l}\text { Full-length double supine A-P-radiograph (Moreland et } \\
\text { al., 1987) }\end{array}$ & $\begin{array}{l}\text { To eliminate the added varus due to deficiency of the } \\
\text { lateral and PL structures }\end{array}$ \\
\hline Real lateral view radiograph (Dejour \& Bonnin, 1994) & To evaluate the posterior tibial slope \\
\hline Merchant's view radiograph (Merchant et al., 1974) & To evaluate the patellofemoral joint \\
\hline Rosenberg's view (Rosenberg et al., 1988) & To evaluate the lateral compartment of the knee \\
\hline Stress radiograph & Purpose \\
\hline $\begin{array}{l}\text { Lateral stress view according to the Telos method } \\
\text { (Jacobsen, 1976; Strobel et al., 2002) }\end{array}$ & $\begin{array}{l}\text { To evaluate the anterior and posterior tibial translation } \\
\text { with respect to the femur }\end{array}$ \\
\hline $\begin{array}{l}\text { Lateral stress view according to the kneeling method } \\
\text { (Louisia et al., 2005) }\end{array}$ & $\begin{array}{l}\text { To evaluate the anterior and posterior tibial translation } \\
\text { with respect to the femur }\end{array}$ \\
\hline $\begin{array}{l}\text { Lateral stress view with hamstring contraction method } \\
\text { (Chassaing et al., 1995) }\end{array}$ & $\begin{array}{l}\text { To evaluate the anterior and posterior tibial translation } \\
\text { with respect to femur }\end{array}$ \\
\hline $\begin{array}{l}\text { Lateral stress view according to the gravity method } \\
\text { (Stäubli \& Jakob, 1990) }\end{array}$ & $\begin{array}{l}\text { To evaluate the anterior and posterior tibial translation } \\
\text { with respect to the femur }\end{array}$ \\
\hline Axial stress view (Puddu et al., 2000) & $\begin{array}{l}\text { To evaluate the anterior and posterior tibial translation } \\
\text { with respect to the femur }\end{array}$ \\
\hline
\end{tabular}

Table 2. Imaging views and their purpose for standard and stress radiographs (Savarese et al., 2011). 


\section{Preoperative planning}

Preoperative planning of the osteotomy is mandatory (Freiling et al., 2010; Pape et al., 2007). The outcome will depend strongly on achieving an optimal and exact degree of correction (Pape et al., 2004). An analysis of knee malalignment includes 5 criteria as listed in Table 3 (Hofmann \& Pietsch, 2007).

\begin{tabular}{|ll|}
\hline 1. & Frontal mechanical axis \\
\hline 2. & Joint line \\
\hline 3. & Sagittal mechanical axis \\
\hline 4. & Patellofemoral joint \\
\hline 5. & Malrotation \\
\hline
\end{tabular}

Table 3. The 5 criteria for analysing knee deformities (Hofmann \& Pietsch, 2007).

The malalignment test is used for cases in which there is a frontal mechanical axis deviation (Paley et al., 1994). The normal axis passes $10 \mathrm{~mm}$ medial of the centre of the knee joint in the region of the tibial spine (ranging from 3 to $17 \mathrm{~mm}$ ) (Paley et al., 1992) (Table 4). Frontal malalignment may result from a femoral deformity, a tibial deformity, knee joint laxity and luxation, an intra-articular condylar deficiency of the knee joint, reduced joint space due to meniscus or cartilage lesions, or any combination of the above (Dugdale et al., 1992; Paley et al., 1994). The intersection point of the proximal and distal mechanical axes is called the centre of rotation of angulation (CORA) (Paley et al., 1994). The axis of correction of angulation and the osteotomy should pass through the same CORA to avoid displacement of the bone ends. The osteotomy should maintain neutral joint-line obliquity and thus not increase the shear stresses at the joint surface (Babis et al., 2002). Excessive obliquity prevents the shift of weight bearing to the lateral compartment and may cause a recurrence of the varus deformity following high tibial osteotomy (Terauchi et al., 2002). (Levigne and Bonnin, 1991) differentiated congenital tibial bone varus (TBVA) from acquired tibial varus malalignment, which results from bone wear in medial gonarthrosis. A high tibial osteotomy can cure tibial bone varus, whereas in acquired tibial varus malalignment it is only a palliative procedure (Bonnin \& Chambat, 2004). Patients with varus malalignment and normal TBVA $\left(<5^{\circ}\right)$ and medial proximal tibial angle (MPTA, $\left.85-90^{\circ}\right)$ have a bone varus of the distal femur (lateral distal femoral angle, LDFA $>90^{\circ}$ ) (Hofmann et al., 2009).

\begin{tabular}{|ll|}
\hline 1. & Mechanical tibiofemoral angle \\
\hline 2. & Mechanical axis (Mikulicz-line) \\
\hline 3. & The total transverse line through the knee (joint line is given as $100 \%)$ \\
\hline 4. & Lateral distal femoral angle (LDFA) $88^{\circ}\left(85-90^{\circ}\right)$ \\
\hline 5. & Medial proximal tibial angle (MPTA) $87^{\circ}\left(85-90^{\circ}\right)$ \\
\hline 6. & Joint line convergence angle (JLCA) $2^{\circ}\left(1-3^{\circ}\right)$ \\
\hline 7. & Joint line (JL) $87^{\circ}\left(84-90^{\circ}\right)$ \\
\hline 8. & Mechanical axis deviation (MAD) $10 \mathrm{~mm}$ medial $(3-17 \mathrm{~mm})$ \\
\hline 9. & Centre of rotation of angulation $(\mathrm{CORA})$ \\
\hline 10. & Tibial bone varus angle (TBVA) $0^{\circ}\left(<0-5^{\circ}\right)$ \\
\hline
\end{tabular}

Table 4. Biomechanical parameters in the frontal plane (Bonnin \& Chambat, 2004; Brown \& Amendola, 2000; Fick, 1911; Hofmann \& Pietsch, 2007; Paley et al., 1994) 
The posterior distal femoral angle (PDFA) helps one to differentiate between bone- and soft tissue-dependant hyperextension or a flexion contracture (Bonin et al., 2004). Changes in the posterior proximal tibial angle (PPTA) or the posterior tibial slope have a strong effect on cartilage pressure and kinematics of the knee (Agneskirchner et al., 2004). With the exception of rare circumstances, the normal tibial slope should not be changed (Hofmann et al., 2009) (Table 5).

\begin{tabular}{|l|}
\hline Posterior distal femoral angle (PDFA) $83^{\circ}\left(79-87^{\circ}\right)$ \\
\hline Posterior proximal tibial angle (PPTA, posterior tibial slope) $81^{\circ}\left(77-84^{\circ}\right)$ \\
\hline
\end{tabular}

Table 5. Biomechanical parameters in the sagittal plane (Paley et al., 1994)

A closing-wedge high tibial osteotomy decreases the posterior slope, translates the tibia in the posterior direction and stabilises a knee that has anterior instability, whereas a medial opening wedge high tibial osteotomy increases the posterior tibial slope, translates the tibia in the anterior direction, and stabilises a knee that has posterior instability (Giffin et al., 2007; Hohmann et al., 2006; Lerat et al., 1993; Savarese et al., 2011). The slope must be raised only slightly, as an elevation in the slope of more than $10^{\circ}$ can cause a chronic insufficiency in the anterior cruciate ligament (Dejour et al., 2000).

Changes in the mechanics of the patellofemoral joint can also result in changes in the tibiofemoral compartments (Feller et al., 2007) (Table 6). A medial open-wedge high tibial osteotomy improves the symptoms of patellofemoral osteoarthritis because the anterior translation of the tibia reduces the tension on the patellar tendon, the patella becomes less horizontal, and pressure decreases in the lateral facet (Kumagai et al., 2002; Li et al., 2002; Savarese et al., 2011). When faced with a patellofemoral malfunction, it is important to check all of the soft tissues and the articular geometry factors that relate to the patella locally and to not neglect the overall alignment and function of the lower limb (Feller et al., 2007). Weight bearing skyline views of the patella with both knees at $30^{\circ}$ flexion, both as the tibial tuberosity-trochlear groove (TT-TG) distance that measured with the CT-scan is an important factor for analysing patellofemoral malfunction (Dejour et al., 1994).

\begin{tabular}{|l|}
\hline $\begin{array}{l}\text { No trochlear dysplasia (no crossing sign with trochlea bump }>3 \mathrm{~mm} \text { and trochlea depth } \\
<4 \mathrm{~mm})\end{array}$ \\
\hline No quadriceps dysplasia with no patellar tilt $>20 \%$ in extension \\
\hline Caton-Deschamps Index 1.0 $(0.8-1.2)$ (Caton, 1989) \\
\hline Insall-Salvati Index $1.0(0.8-1.2)($ Insall \& Salvati, 1971) \\
\hline Blackburne-Peel Index 0.8 (0.5-1.0) (Blackburne \& Peel, 1977) \\
\hline Tibial tuberosity-trochlea groove (TT-TG) distance <15 mm \\
\hline Congruence angle $-6^{\circ}+11^{\circ}$ (Merchant et al., 1974) \\
\hline Axial linear patellar displacement (Urch et al., 2009) \\
\hline Patellar tilt angle $2^{\circ}+5^{\circ}$ (Grelsamer et al., 1993) \\
\hline Sulcus angle (Brattstroem, 1964) \\
\hline
\end{tabular}

Table 6. Biomechanical parameters in the patellofemoral joint

A CT scan or MRI of the leg is recommended in malrotations during the preoperative clinical evaluation. 


\section{Planning of post-operative correction}

The post-operative correction is typically planned with the use of full-length A-P view standing radiographs with the patella facing directly anterior with the patient standing on both legs according to the method of Miniaci et al. (M Galla \& Lobenhoffer, 2004; Miniaci et al., 1989).

Alternatively, the post-operative correction can be planned according to the methods of (Dugdale et al., 1992 or Coventry, 1985). (Coventry, 1985) recommended a postoperative anatomical valgus of at least $8^{\circ}$. The correction that is achieved can also be verified by measuring the mechanical tibiofemoral angle (Hernigou et al., 1987; Ivarsson et al., 1990). The point where the mechanical axis crosses the transverse diameter of the tibial plateau is the recommended planning method (Pape et al., 2007) Table 6 (Noyes et al., 1993). The mechanical axis is shifted to a point that is $62 \%$ of the transverse diameter of the tibial plateau (Fujisawa et al., 1979) (Table 7). In a biomechanical study under reproducible dynamic loading conditions using pressure-sensitive films with the corrected axis running through the "Fujisawa point", the load changed only after the complete release of the MCL from medial to lateral $(64 \%)$ (Agneskirchner et al., 2007). An individual correction of varus deformities between $0^{\circ}$ and $6^{\circ}$ of the mechanical valgus or shifting the mechanical axis to a point between $55 \%$ and $67.5 \%$ on the transverse diameter of the tibial plateau according to the intra-articular disease is also recommended (Fig. 2 and Table 8). Post-operative correction can also be planned with an arthroscopy before the osteotomy based on the Outerbridge classification (Fig. 3) (Müller \& Strecker, 2008; Outerbridge, 1961). Digital radiographs require calibration before planning (Freiling et al., 2010). A large flexion deformity in varus knees precludes the precise planning of deformity correction, as the degree of the varus malalignment will be overestimated (Pape et al., 2004). To support planning deformities with TomoFix (Synthes, West Chester, Pennsylvania), the tool PreOp-Plan was developed by Siemens.

\begin{tabular}{|c|c|c|c|}
\hline Authors (Reference) & Preoperative planning & $\begin{array}{c}\text { Recommended } \\
\text { postoperative correction } \\
\text { angle }\left(^{\circ}\right)\end{array}$ & $\begin{array}{c}\text { Point where the } \\
\text { mechanical axis crosses } \\
\text { the tibial plateau }(\%)\end{array}$ \\
\hline Coventry (Coventry, 1985) & $\begin{array}{l}\text { Anatomical tibiofemoral } \\
\text { angle }\end{array}$ & $8-10$ & - \\
\hline $\begin{array}{l}\text { Koshino et al. (Koshino et } \\
\text { al., 1989) }\end{array}$ & $\begin{array}{l}\text { Anatomical tibiofemoral } \\
\text { angle }\end{array}$ & $6-15$ & - \\
\hline $\begin{array}{l}\text { Engel \& Lippert } \\
\text { (Engel \& Lippert, 1981) }\end{array}$ & $\begin{array}{l}\text { Anatomical tibiofemoral } \\
\text { angle }\end{array}$ & $5-10$ & - \\
\hline $\begin{array}{l}\text { Kettelkamp (Kettelkamp } \\
\text { et al., 1976) }\end{array}$ & $\begin{array}{l}\text { Anatomical tibiofemoral } \\
\text { angle }\end{array}$ & $>5$ & - \\
\hline $\begin{array}{l}\text { Aglietti et al. } \\
\text { (Aglietti et al., 2003) }\end{array}$ & $\begin{array}{l}\text { Anatomical tibiofemoral } \\
\text { angle }\end{array}$ & $8-15$ & \\
\hline $\begin{array}{l}\text { Hernigou et al. (Hernigou } \\
\text { et al., 1987) }\end{array}$ & $\begin{array}{l}\text { Mechanical tibiofemoral } \\
\text { angle }\end{array}$ & $3-6$ & - \\
\hline $\begin{array}{l}\text { Ivarson et al. } \\
\text { (Ivarson et al., 1990) }\end{array}$ & $\begin{array}{l}\text { Mechanical tibiofemoral } \\
\text { angle }\end{array}$ & $3-7$ & - \\
\hline $\begin{array}{l}\text { Myrnerts } \\
\text { (Myrnerts, 1980) }\end{array}$ & $\begin{array}{l}\text { Mechanical tibiofemoral } \\
\text { angle }\end{array}$ & $3-7$ & - \\
\hline $\begin{array}{l}\text { Miniaci et al. } \\
\text { (Miniaci et al., 1989) }\end{array}$ & Mechanical axis & - & $60-70$ \\
\hline $\begin{array}{l}\text { Dugdale } \\
\text { (Dugdale et al., 1992) }\end{array}$ & Mechanical axis & - & $50-75$ \\
\hline $\begin{array}{l}\text { Noyes } \\
\text { (Noyes et al. 1993) }\end{array}$ & Mechanical axis & - & 62 \\
\hline
\end{tabular}

Table 7. Recommended correction angles and lines (Pape et al., 2004; Pape et al., 2007) 


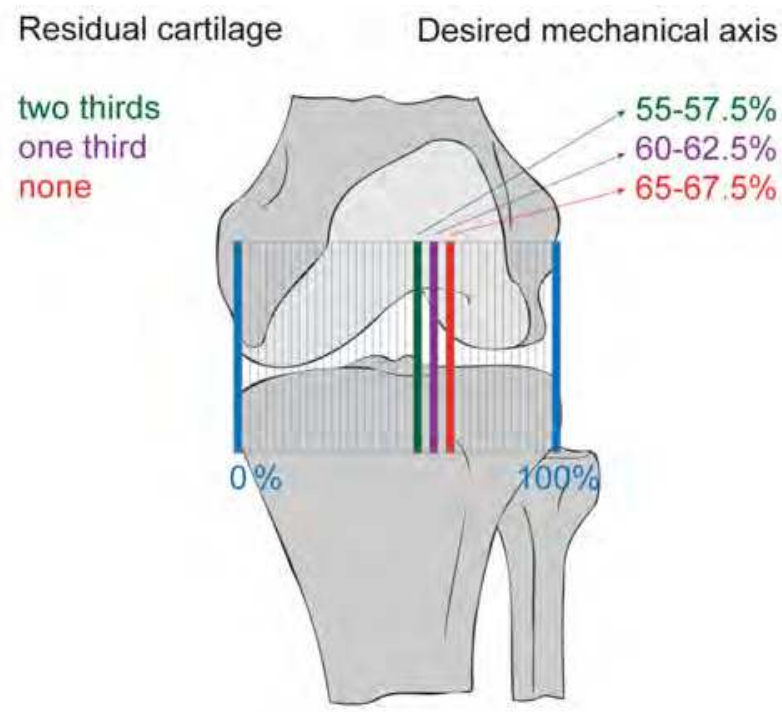

Fig. 2. Correction of varus deformities (Marti et al., 2004; Jakob \&Jacobi, 2004)

Planned correction at $\triangle \mathrm{CM}$

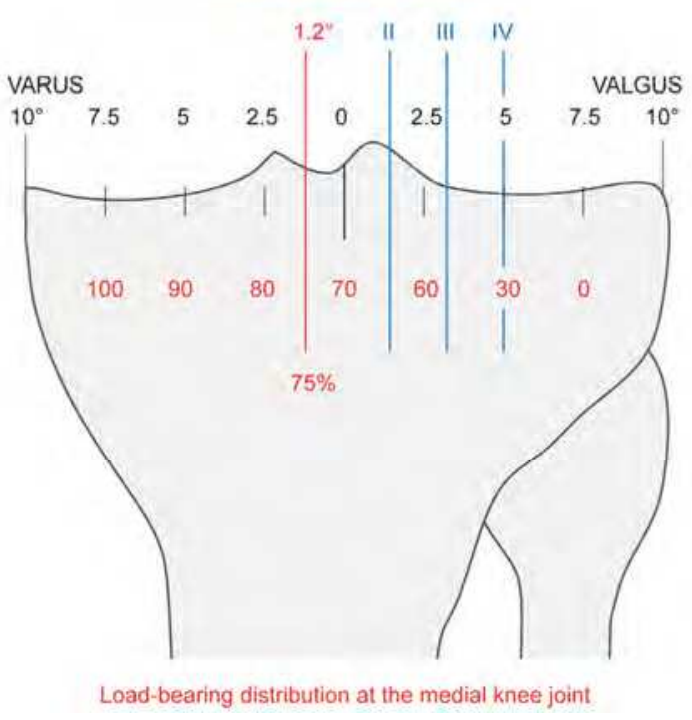

Fig. 3. Planned correction in high tibial valgus osteotomies. The load bearing distribution at the medial knee depending on the frontal axis of the leg (normal $75 \%$ according to Hsu et al., 1990) is in red, and the correction angle depending on $\triangle \mathrm{CM}$ (Cartilage lesion) according to the Outerbridge classification (Outerbridge, 1961) is in blue. The planned correction angles were as follow: at $\Delta \mathrm{CM}=\mathrm{IV}^{\circ} 5^{\circ}$ of valgus, at $\Delta \mathrm{CM}=\mathrm{III}^{\circ}$ the Fujisawa point $\left(3.3^{\circ}\right.$ of valgus) and at $\Delta \mathrm{CM}=\mathrm{II}^{\circ} 1.7^{\circ}$ of valgus (Müller \& Strecker, 2008; Strecker et al. 2009). 


\begin{tabular}{|l|l|}
\hline $\begin{array}{l}\text { Posttraumatic malalignment without } \\
\text { osteoarthritis }\end{array}$ & $0-2^{\circ}$ \\
\hline ACL insufficiency & $0-2^{\circ}$ \\
\hline PCL insufficiency & $2-4(5)^{\circ}$ \\
\hline Surgery of chondral lesions & $3-5^{\circ}$ \\
\hline
\end{tabular}

Table 8. Correction angles of varus deformities for the different types of disorders (Müller, 2001; Hofmann et al., 2009)

The first step is to draw the $\mathrm{z}$-line from the centre of the femoral head to the centre of the talus (Fig. 4). In varus malalignment, the mechanical axis passes the tibial plateau more medially than the physiological mechanical axis deviation (MAD) of $10 \mathrm{~mm}$ (ranging from 3 to $17 \mathrm{~mm}$ ). Next, a line that is parallel to the tibial plateau is drawn. A third line is drawn with the desired mechanical axis from the centre of the femoral head to a point $62 \%$ lateral on the transverse diameter of the tibial plateau (Fujisawa et al., 1979). The desired mechanical axis is continued to the centre of the ankle in its postoperative position. The centre of rotation of angulation (CORA) lies in the lateral cortex at the tip of the fibula. Line 1 connects CORA with the middle of the ankle joint. Line 2 is drawn from CORA to the centre of the ankle in its postoperative position and crosses the desired mechanical axis at the centre of the ankle. The angle between lines 1 and 2 forms the correction angle. The degree of lateral separation (the joint line convergence angle, or JLCA) from the apparent deformity in the preoperative planning of the correction angle is subtracted (Kolb et al., 2010).

Alternatively the JLCA can be determined preoperatively from the full-length A-P view standing radiographs of both knees. The difference $\Delta a$ between both JLCAs is measured (Pape et al., 2004). By taking the width of the tibial plateaus (WTP) and a constant K (76.4) into consideration, the varus malalignment that is caused by the ligamentous instability $(\beta)$ can be determined using the following equation: $\beta=K \times(\Delta \mathrm{a}) /$ WTP (Galla \& Lobenhoffer, 2004). The angle $\beta$ is then subtracted from the measured angle of correction (Pape et al., 2004; Galla \& Lobenhoffer, 2004).

Ideal correction of the leg of the leg is difficult to achieve, and postoperative malalignment is often observed following high tibial osteotomy (Dahl, 2000; Noyes et al., 2000). The challenge for achieving a permanent surgical solution is to achieve the planned axis intraoperatively (Gebhard et al., 2011). Computer-assisted navigation systems may improve the precision and accuracy of the leg axis correction while offering simulation tools that can predict the postoperative alignment (Gebhard et al., 2011) (Fig. 5). The integration of "computer-aided design/computer-aided manufacturing (CAD/CAM)" planning into computer-assisted surgery allows one to plan complex orthopaedic surgical procedures (Wong et al., 2010).

\section{Surgical technique}

An arthroscopy is first performed to check the indication for an osteotomy, to modify the planned correction according to the intra-articular findings and to rule out and treat the intraarticular pathologies (Fig. 3) (Strecker et al., 2009). Meniscal tears, loose bodies, osteophytic spurs, and chondral flaps can cause mechanical symptoms that can be treated successfully with arthroscopy (Iorio \& Healy, 2003). In 51 out of 300 cases (17\%), the procedure was changed to a total knee arthroplasty due to finding of advanced osteoarthritis in the intended compartment during the preoperative arthroscopy (Strecker et al., 2009). 


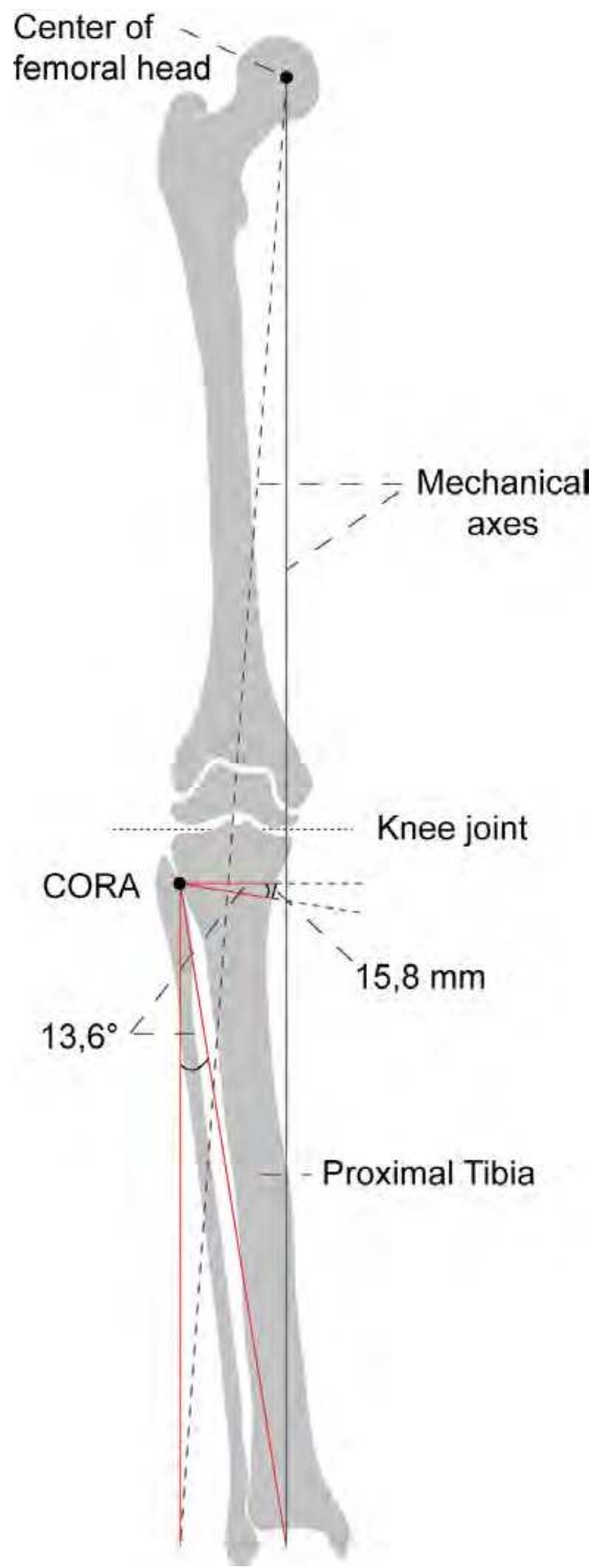

Fig. 4. Planning of post-operative correction for an open wedge high tibial osteotomy. 


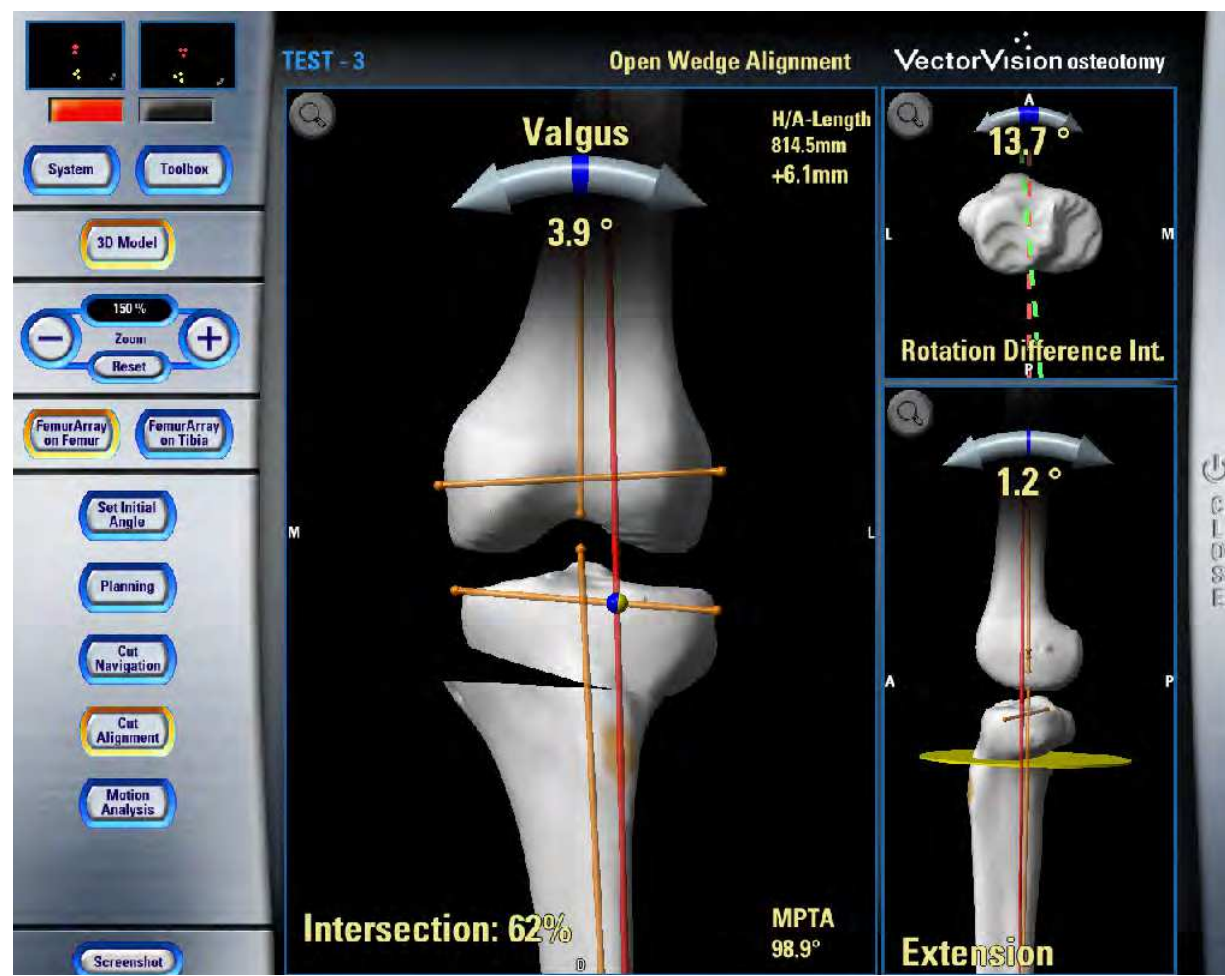

Fig. 5. High tibial osteotomy with a computer-assisted navigation system (From BRAINLAB with permission)

Lateral open-wedge high tibial osteotomies are rarely performed. There is a paucity reports regarding the use of a reconstructive osteotomy to treat depression and valgus malunions of the proximal tibia (Kerkhoffs et al., 2008).

Barrel-vault (dome) osteotomies, lateral-closed-wedge, medial open-wedge high tibial osteotomies or a procedure that combines these techniques are used to treat varus deformities of the knee (Coventry, 1965; M Galla \& Lobenhoffer, 2004; Hernigou et al. 1987; Maquet, 1976; Nagi et al., 2007; Watanabe et al., 2008; Weber \& Wörsdörfer, 1980). Patellofemoral pain due to patella baja, large deformities or high tibial slope is an indication for performing a closed-wedge osteotomy (Marti et al., 2004). Small deformities and medial instability are indications for open-wedge osteotomies.

Lateral closed-wedge high tibial osteotomies have been the treatment of choice since 1965 (Coventry, 1965). The closed wedge is the most stable high tibial osteotomy technique when compared with the open-wedge osteotomy and the barrel-vault (dome) osteotomy, as the periosteum and cortex adjacent to the apex of the removed wedge act as a tether when the osteotomy is closed (Hansen \& Chao, 1994, Kolb et al., 2009). Several lateral tensioning systems such as 1/3 tubular plates with cortical bone screws, a 4.5-mm L-plate, bone staples, external fixation devices, Giebel plates and locked plates are used (Billings et al., 2000; Coventry, 1969; Giebel et al., 1985; Jackson \& Waugh, 1961; Kessler et al. 2002; Luites et al., 2009; Perusi et al., 1994; Weber \& Wörsdörfer, 1980). 
We have used the modified Weber-technique (Weber \& Wörsdörfer, 1980), which provides several advantages, including high stability of the osteotomy through the tension band principle with large bone contact areas and the possibility of bone impaction, intraoperative correction of the osteotomy, no large implant (in particular, no removal of the implant is necessary), no increase in pressure in the medial compartment through tensioning of the MCL, no increase of pressure in the patellofemoral joint and no bone graft (Frey et al., 2008).

The most common problems associated with this procedure are difficulty in achieving an accurate correction of the osseous malalignment, the need for fibular osteotomy or separation of the proximal tibiofibular joint, contracture of the patellar tendon leading to patellar baja, leg shortening, and a high rate of other complications (Aydogdu et al., 2000; Kirgis \& Albrecht, 1992; Tunggal et al., 2010) (Tables 9 and 10). Large corrections may cause marked shortening of the leg and a large offset of the tibia, which may compromise the later placement of the tibial component during a total knee replacement (Brinkman et al., 2008).

(Shaw et al., 2004) conducted an anatomical study and found that an osteotomy angle greater than $10^{\circ}$ rendered the lateral collateral ligament non-functional and allowed the knee to swing back to its native alignment with varus loading, thus negating much of the bony correction.

\begin{tabular}{|l|l|}
\hline Infection & $0.8-10.4 \%$ \\
\hline Thromboembolic disease & $2-5 \%$ \\
\hline Compartment syndrome & Rare \\
\hline Fracture of the medial cortex & $82 \%$ \\
\hline Intra-articular fractures & $0-20 \%$ \\
\hline Non-union & $1-5 \%$ \\
\hline Delayed union & $4-8.5 \%$ \\
\hline Peroneal nerve palsy & $0-27 \%$ \\
\hline
\end{tabular}

Table 9. Complications (and their incidence) of closed-wedge high tibial osteotomy (Staubli \& Jacob, 2010, Tunggal et al., 2010)

\begin{tabular}{|ll|}
\hline - & $\begin{array}{l}\text { No difference in the incidence of infection, deep vein thrombosis, peroneal nerve } \\
\text { palsy, non-union or revision to knee arthroplasty }(\mathrm{p}>0.05)\end{array}$ \\
\hline - & $\begin{array}{l}\text { Significantly greater posterior tibial slope and mean angle of correction, reduced } \\
\text { patellar height and hip-knee-ankle angle following opening-wedge } \mathrm{HTO}(\mathrm{p}<0.05)\end{array}$ \\
\hline - & $\begin{array}{l}\text { No significant difference was found for any clinical outcome including pain, } \\
\text { functional score or complications }(\mathrm{p}>0.05)\end{array}$ \\
\hline
\end{tabular}

Table 10. Differences in complications between Open- or closed-wedge high tibial osteotomies (Smith et al. 2010).

The open-wedge high tibial osteotomy gained recognition after the encouraging reports of (Hernigou et al., 1987). A medial open-wedge osteotomy proximal to the tibial tubercle was performed, and appropriate-size wedges of bone that were obtained from the iliac 
crest were inserted into the defect (Hernigou et al., 1987; Poignard et al., 2010). No internal fixation or plaster was used. A crack in the lateral cortex during or after the osteotomy may cause a displacement and a subsequent loss of correction (Hernigou et al., 1987). Therefore, we now perform internal fixation using a plate and screws for all osteotomies (Poignard et al., 2010). Modern techniques involve sawing and chiselling through the bone and the application of an internal (or external) splint to fix the fragments in the required juxtaposition until bone healing is complete (Staubli \& Jacob, 2010; Merian et al., 2005; Weale et al., 2001). Because of the well-known morbidity of the relevant donor site, bone substitutes such as DUOWEDGE (from Intrauma, Rivoli, Italy) can be employed (Poignard et al., 2010). However, the outcome often falls short of the expected result, and much effort is currently being expended to improve this outcome. The surgical technique was improved by applying a combination of the MIPO-technique with a V-shaped osteotomy and an internal fixator. The V-shaped osteotomy provides additional room for the adequate fixation of any device to the proximal fragment (i.e., 5 $\mathrm{cm}$ distal to the joint line rather than only $3.5 \mathrm{~cm}$ ) (Hernigou et al., 1987; Lobenhoffer et al., 2002). The V-shaped osteotomy further improves the rotational and sagittal stability (Lobenhoffer et al., 2002). The anterior bone contact supports healing of the osteotomy and prevents intraoperative malrotation, forward slipping and tilting (Freiling et al., 2010; Van Heerwarden et al., 2007). Lastly, the force transmission of the patellar tendon is not compromised (Staubli \& Jacob, 2010).

The TomoFix internal fixator is anatomically pre-contoured for the proximal-medial aspect of the tibia, which allows healing of the osteotomy without compression between the plate and bone and promotes osteogenesis through angular stable fixation with the precise amount of elasticity (Brinkman et al., 2008; Kolb et al., 2009; Nelissen et al., 2010). The angle of correction is maintained, thereby avoiding a later loss of correction (Kolb et al., 2009; Staubli et al., 2003; Stoffel et al., 2004).

The following surgical technique was developed by Lobenhoffer et al., 2002 and Staubli et al., 2003 (Kolb et al., 2009, 2010)

The procedure is performed with the patient placed in a supine position on a radiolucent table with a lateral support. With the knee held at $90^{\circ}$ of flexion, the medial side of the proximal tibia is exposed by a 6 to $8 \mathrm{~cm}$ oblique incision $4 \mathrm{~cm}$ distal to the joint line extending from the medial aspect of the tibial tuberosity to the posterior border of the tibial plateau.

The superficial fibres of the medial collateral ligament are mobilised and released (Fig. 6). The knee is then extended, and two 2.5-mm Kirschner wires mark the oblique osteotomy starting proximal to the pes anserinus $5 \mathrm{~cm}$ distal to the joint line (Figs. 6 and 7).

The wires then extend to the tip of the fibula. A V-shaped osteotomy is then performed with the knee flexed again. The oblique osteotomy is performed in the posterior two-thirds of the tibia while leaving a $10-\mathrm{mm}$ lateral bone bridge intact. To prevent an unintentded increase in the posterior tibial slope, special attention should be paid in locating the intact cortical hinge on the lateral - not posterolateral - side of the tibia (Wang et al., 2009)

The second osteotomy begins in the anterior one-third of the tibia at an angle of $135^{\circ}$ while leaving the tibial tuberosity intact (a proximal-tuberosity osteotomy, or PTO, Fig. 8). When jigs are not available, a significant improvement in cutting accuracy can be achieved using a navigating system or an industrial robot that is integrated into the freehand bone-cutting (Cartiaux et al., 2010). 
Fig. 6. $2.5 \mathrm{~mm}$ Kirschner wire mark the oblique osteotomy
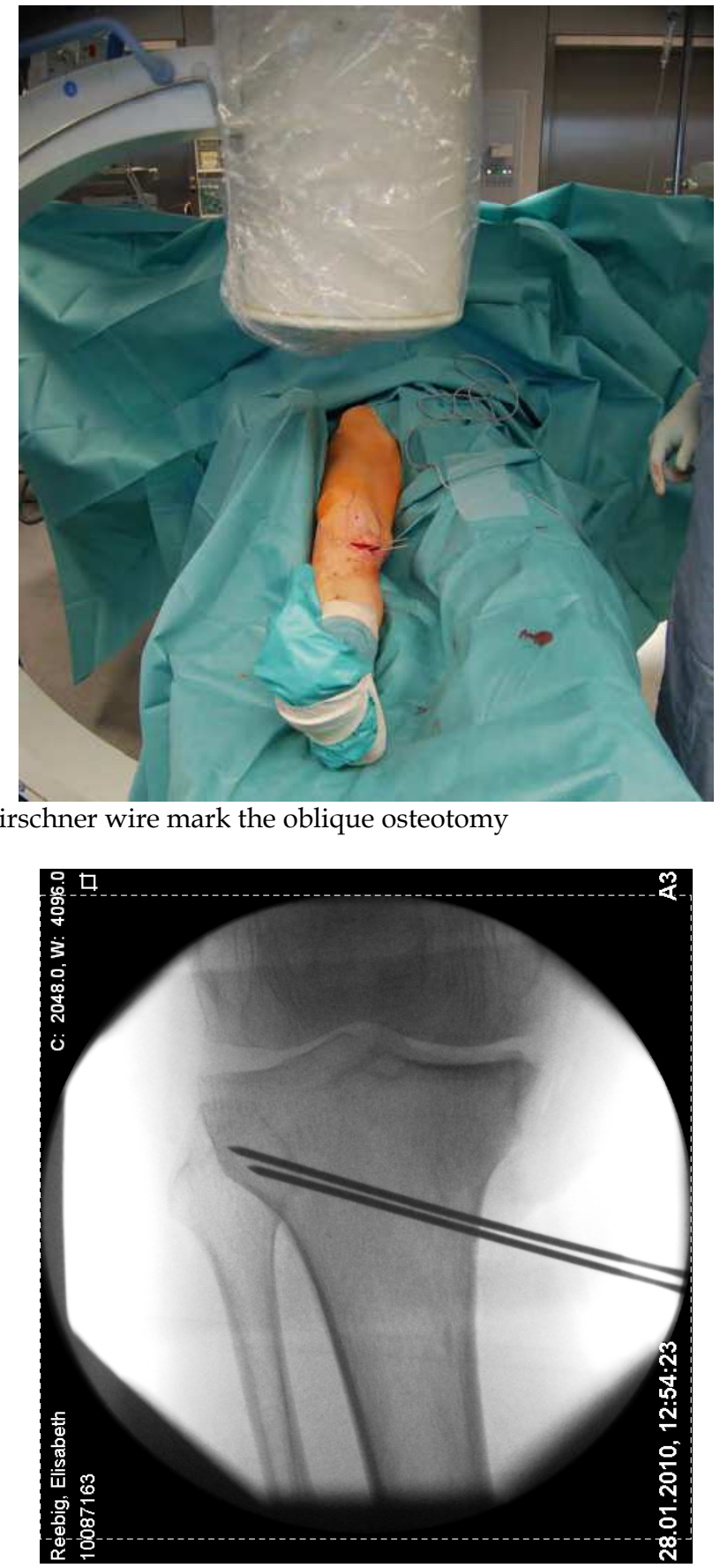

Fig. 7. $2.5 \mathrm{~mm}$ Kirschner wire mark the oblique osteotomy 


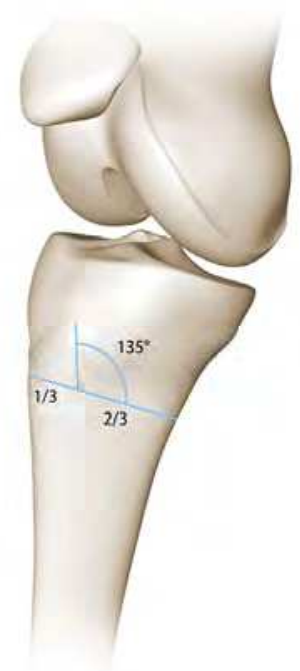

Fig. 8. V-shaped open-wedge high tibial osteotomy

We open the oblique osteotomy stepwise using three stacked osteotomes and a calibrated wedge spreader. The alignment is verified using the cable method (Krettek et al., 1997) or, alternatively, a rigid bar (Brinkman et al., 2008) or an axis-board (Liodakis et al., 2010). The axis-board is a simple and convenient option for intraoperative evaluation of the mechanical axis (Liodakis et al., 2010); however, for complex corrections, the use of navigation systems is still recommended (Liodakis et al. 2010). In recent studies, computer-assisted surgery has proven to be a helpful tool for the intraoperative control of the leg axis (Bae et al., 2009; Lützner et al., 2010; Gebhard et al., 2011), as it provides additional information regarding the lateral plane, ligaments and extension (Heijens et al., 2009). Moreover, 3D navigation can provide surgeons with reliable information both to determine the appropriate coronal alignment and to maintain the anatomical tibial slope during the open-wedge high tibial osteotomy procedure (Yamamoto et al., 2008). With the addition of arthroscopy, the anatomy and landmarks of the proximal tibia can be fully utilised to determine the frontal alignment and tibial slope (Lo et al., 2009). In a first prospective case series, approximately $85 \%$, of patients achieved perfect result in terms of deviaton of the planned mechanical axis using computer assistance as an intraoperative guiding tool (Gebhard et al., 2011).

The alignment is checked with the knee fully extended. The TomoFix internal fixator is inserted into a subcutaneous tunnel on the anteromedial aspect of the tibia (Fig. 9).

The posterior tibial slope depends on the position of the plate that is used to stabilise the osteotomy (Rodner et al., 2006, Saverese et al., 2011). An anterior plate position results in an increase in the posterior tibial slope by an average of $6.6^{\circ}$ (Rodner et al., 2006). In a large openwedge correction (i.e., $>8^{\circ}$ to $10^{\circ}$ ) or in the cases of a preoperative patella infera, the tibial tuberosity is cut distally with a modified distal-tuberosity osteotomy (DTO) (Gaasbeek et al., 2004; Brinkman et al., 2008). (Poignard et al., 2010) recommend open medially and posteriorly to avoid increasing the posterior slope and unducing patella baja. We use cancellous bone grafts for open-wedge osteotomies that exceed $15 \mathrm{~mm}$, whereas (Brinkman et al. 2008) uses 
these bone grafts when the open-wedge osteotomy exceeds $20 \mathrm{~mm}$. (Poignard et al., 2010) recently reported the use of the porous beta-tricalcium phosphate (Beta-TCP) DOUWEDGE.

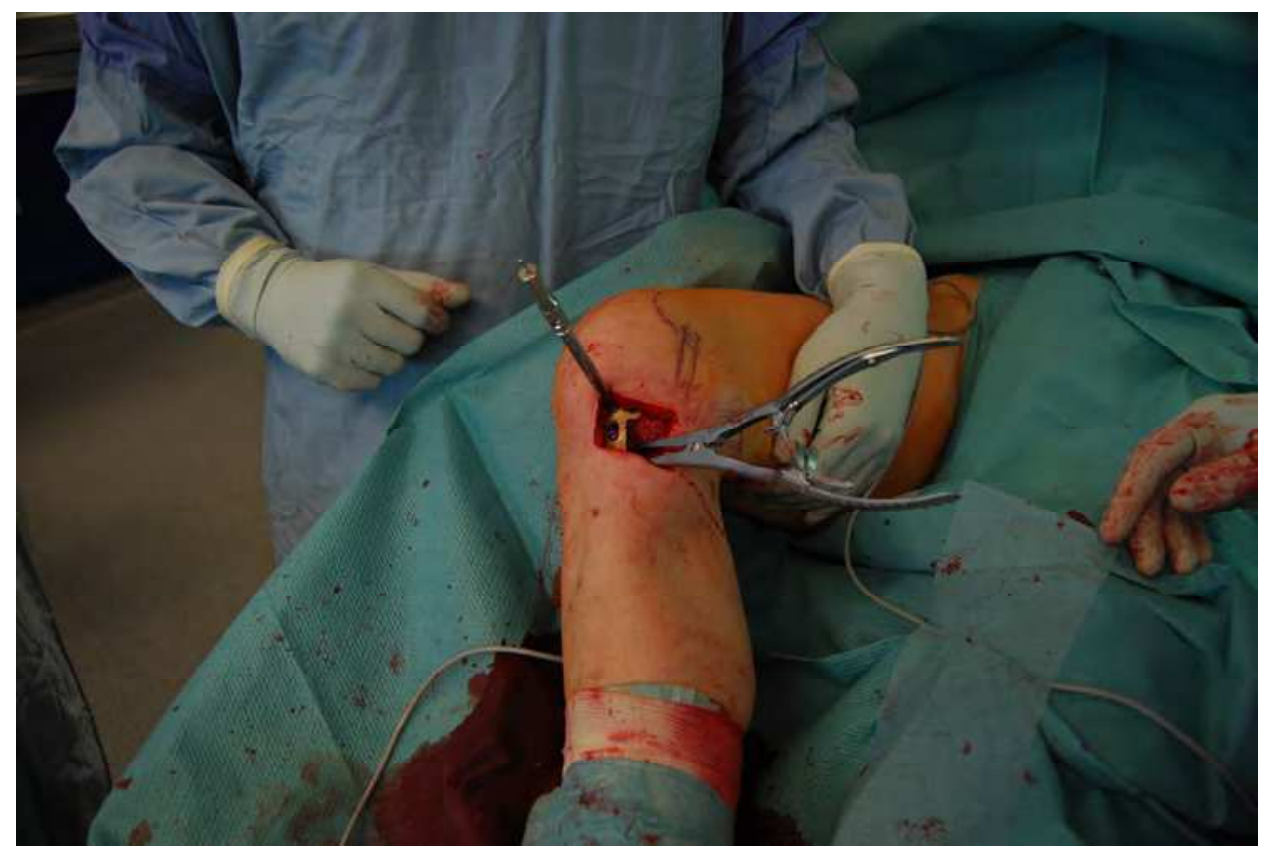

Fig. 9. The TomoFix is inserted into a subcutaneous tunnel

\subsection{Postoperative care}

Beginning on their first postoperative day, the patient is limited to partial weight bearing (15 $\mathrm{kg}$ to $20 \mathrm{~kg}$ ) for six weeks, after which the patient can begin full weightbearing. According to (Brinkman et al., 2010) patients can typically begin full weight bearing-depending on painafter two to three weeks (Brinkman et al., 2010).

\section{Results}

The open-wedge high tibial osteotomy with the MIPO technique using the TomoFix internal fixator obtained significant improved clinical results after a short to medium term follow-up (Table 10). Postoperatively, the infection rate, the rate of delayed and non-unions, the intraarticular fracture rate and the rate of implant failures were low (Table 11). Smokers had a higher rate of non-unions (Meidinger et al., 2009) (Table 12). The reason for the low complication rate of the MIPO technique with the TomoFix internal fixator was its high stability that allows a larger distance between the two screws that are adjacent to the osteotomy, thereby resulting in less elastic deformation of the plate and interfragmantary tissue. A high percentage of patients (41\%) complained of local irritation that was associated with the implant in the clinical course after high tibial osteotomy (Table 13, Meidinger et al., 2011). In all cases, irritation disappeared after implant removal upon consolidation of the osteotomy gap (Meidinger et al., 2011). In the meantime, the design of the TomoFix has been modified. 


\begin{tabular}{|c|c|c|c|c|c|}
\hline Author & $\begin{array}{c}\text { Patients (n) } \\
\text { for Follow-up } \\
\text { (n, \%), age } \\
\text { (years) }\end{array}$ & $\begin{array}{c}\text { Mean Follow- } \\
\text { up }\end{array}$ & $\begin{array}{c}\text { Mean results } \\
\text { pre-op } \\
\text { (range) }\end{array}$ & $\begin{array}{l}\text { Mean result at } \\
\text { Follow-up } \\
\text { (range) }\end{array}$ & $\begin{array}{l}\text { Scoring } \\
\text { system }\end{array}$ \\
\hline $\begin{array}{l}\text { Staubli } \\
\text { et al., } 2003\end{array}$ & $\begin{array}{c}90 / 90(100 \%) \\
50(18-75) \\
\text { Years }\end{array}$ & $\begin{array}{l}9 \text { (2-24) } \\
\text { months }\end{array}$ & $4(3.5-5)$ & $\begin{array}{c}2(1.5-3) \\
\text { significant }\end{array}$ & $\begin{array}{l}\text { Visual } \\
\text { Analogue } \\
\text { Scale }\end{array}$ \\
\hline $\begin{array}{l}\text { Galla \& } \\
\text { Lobenhoffer, } \\
2004, \\
\text { Lobenhoffer } \\
\text { et al., } 2004\end{array}$ & $\begin{array}{c}262 / 262 \\
(100 \%), \text { mean } \\
40 \text { years }\end{array}$ & $\begin{array}{l}\text { Osteotomy } \\
\text { healing }\end{array}$ & ND & ND & ND \\
\hline $\begin{array}{l}\text { Takeuchi } \\
\text { et al., } 2009\end{array}$ & $\begin{array}{c}52 / 52(100 \%) \\
69(54-82) \\
\text { years, } 57 \\
\text { knees }\end{array}$ & $\begin{array}{l}40(24-62) \\
\text { months }\end{array}$ & $50.9 \pm 12.3$ & $\begin{array}{l}91.7 \pm 6.9 \\
\text { significant }\end{array}$ & $\begin{array}{l}\text { American } \\
\text { Knee Society } \\
\text { Score and } \\
\text { Function } \\
\text { Score }\end{array}$ \\
\hline $\begin{array}{l}\text { Valkering et al., } \\
2009\end{array}$ & $40 / 40(100 \%)$ & $\begin{array}{l}\text { Mean } 10.4 \\
\text { months }\end{array}$ & ND & ND & ND \\
\hline $\begin{array}{l}\text { Zaki \& Rae, } \\
2009\end{array}$ & $\begin{array}{c}46(46(100 \%) \\
50 \text { knees }\end{array}$ & $\begin{array}{l}60(36-72) \\
\text { months }\end{array}$ & $\begin{array}{l}48(38-54) \\
38(30-55) \\
35(25-55)\end{array}$ & $\begin{array}{c}22(17-31) \\
(\mathrm{p}<0.05) \\
82(45-92) \\
(\mathrm{p}<0.05) \\
75(50-95) \\
(\mathrm{p}<.0 \%)\end{array}$ & $\begin{array}{l}\text { Oxford knee } \\
\text { score, Knee } \\
\text { Society score, } \\
\text { functional } \\
\text { score }\end{array}$ \\
\hline Kolb et al., 2009 & $51 / 49(96 \%)$ & $\begin{array}{c}52(28-66) \\
\text { months }\end{array}$ & $\begin{array}{l}65.8(50-98) \\
60.2(43-86)\end{array}$ & $\begin{array}{l}92.9(73-100) \\
90.6(71-100)\end{array}$ & $\begin{array}{c}\text { HSS score, } \\
\text { Lysholm score }\end{array}$ \\
\hline $\begin{array}{l}\text { Niemeyer } \\
\text { et al., } 2010\end{array}$ & $\begin{array}{c}73 / 69(95 \%) \\
46.73 \pm 9.99 \\
\text { years }\end{array}$ & $\begin{array}{c}\text { Minimum } 36 \\
\text { months }\end{array}$ & $\begin{array}{l}47.25 \pm 18.71 \\
54.26+20.76\end{array}$ & $\begin{array}{c}72.72 \pm 17.15 \\
(\mathrm{p}<.001) \\
79.14+16.63 \\
(\mathrm{p}<.001)\end{array}$ & $\begin{array}{l}\text { IKDC score, } \\
\text { Lysholm score }\end{array}$ \\
\hline $\begin{array}{l}\text { Gebhard } \\
\text { et al., } 2011\end{array}$ & \begin{tabular}{|}
$51 / 50(98 \%)$ \\
$45.4 \pm 8.6(22-$ \\
$59)$
\end{tabular} & 6 weeks & ND & ND & ND \\
\hline $\begin{array}{l}\text { Meidinger } \\
\text { et al., } 2011\end{array}$ & $\begin{array}{c}182,142 \text { men, } \\
40.3 \pm 10.6 \\
\text { years, } 40 \\
\text { women, } 43.7 \\
\pm 8.9 \text { years }\end{array}$ & 3 months & ND & ND & ND \\
\hline
\end{tabular}

ND means not determined

Table 11. The results of open-wedge high tibial osteotomy with the TomoFix internal fixator from various studies. 


\begin{tabular}{|c|c|c|c|c|c|}
\hline Author & $\begin{array}{c}\text { Alignment/Correction } \\
\text { losses }\end{array}$ & $\begin{array}{l}\text { Osteotomy } \\
\text { healing } \\
\text { (weeks) }\end{array}$ & Infection (n, \%) & $\begin{array}{l}\text { Implant } \\
\text { failure } \\
(\mathrm{n}, \%)\end{array}$ & $\begin{array}{l}\text { Secondary } \\
\text { surgical } \\
\text { procedure }\end{array}$ \\
\hline $\begin{array}{l}\text { Staubli } \\
\text { et al., } 2003\end{array}$ & $\begin{array}{c}\text { >slope p.o. mean } 0.99, \\
\text { one loss of correction in } \\
\text { both knees }\end{array}$ & 10 & $1(1 \%)$ & 0 & $\begin{array}{l}\text { Implant removal } \\
\text { due to infection }\end{array}$ \\
\hline $\begin{array}{l}\text { Galla \& } \\
\text { Lobenhoffer, } \\
2004, \\
\text { Lobenhoffer } \\
\text { et al., } 2004\end{array}$ & No loss of correction & $\begin{array}{c}2 \text { delayed } \\
\text { union }(0.8 \%)\end{array}$ & $\begin{array}{l}1(0.4 \%) \text { deep } \\
\text { infection } 4 \\
\text { months } \\
\text { postoperative }\end{array}$ & $\begin{array}{l}\text { Breakage 1 } \\
\text { screw }(3 \%)\end{array}$ & $\begin{array}{c}2 \text { secondary } \\
\text { bone grafts } \\
(0.8 \%), 4(2 \%) \\
\text { hematomas, one } \\
(0.4 \%) \text { implant } \\
\text { removal due to } \\
\text { infection, one } \\
\text { revision }(0.4 \%) \\
\text { due to } \\
\text { malalignment } \\
\end{array}$ \\
\hline $\begin{array}{l}\text { Takeuchi } \\
\text { et al., } 2009\end{array}$ & $\begin{array}{c}\text { Mean femorotibial angle } \\
\text { pre-op } 181.3 \pm 2.4^{\circ} \text {, p.o. } \\
169.6 \pm 2.3^{\circ}\end{array}$ & No non-union & ND & 0 & ND \\
\hline $\begin{array}{l}\text { Valkering } \\
\text { et al., } 2009\end{array}$ & $\begin{array}{l}\text { Mean loss of correction } \\
0.3^{\circ} \text {, no loss of correction } \\
\text { after implant removal }\end{array}$ & 10.4 months & $\begin{array}{c}4(10 \%) \\
\text { superficial } \\
\text { infection }\end{array}$ & ND & ND \\
\hline $\begin{array}{l}\text { Zaki \& Rae, } \\
2009\end{array}$ & $\begin{array}{l}\text { Tibio-femoral } 7(5-8)^{\circ} \\
\text { varus pre-op, } 6(5-8)^{\circ} \\
\text { valgus p.o. }\end{array}$ & & $\begin{array}{c}2 \text { superficial } \\
\text { infections }(4 \%)\end{array}$ & ND & ND \\
\hline $\begin{array}{l}\text { Kolb et al., } \\
2009\end{array}$ & $\begin{array}{c}9.5(15-0)^{\circ} \text { varus pre-op, } \\
1.3(-1-5)^{\circ} \text { valgus, no loss } \\
\text { of correction }\end{array}$ & $\begin{array}{c}12.9(8-16) \\
\text { weeks, one } \\
\text { non-union } \\
(2 \%) \\
\end{array}$ & 0 & $\begin{array}{l}\text { No } \\
\text { implant } \\
\text { failure }\end{array}$ & \begin{tabular}{|c|} 
One revision \\
osteosynthesis \\
with bone graft \\
$(2 \%)$ \\
\end{tabular} \\
\hline $\begin{array}{l}\text { Niemeyer } \\
\text { et al., } 2010\end{array}$ & $\begin{array}{l}3(4 \%) \text { overcorrection } \\
\text { mechanical axis }>70 \% \\
\text { transverse diameter of } \\
\text { proximal tibia, }\end{array}$ & $\begin{array}{c}2(3 \%) \text { delayed } \\
\text { union }\end{array}$ & $\begin{array}{l}1(1 \%) \\
\text { superficial } \\
\text { wound } \\
\text { infection }\end{array}$ & $\begin{array}{c}28(41 \%) \\
\text { local } \\
\text { irritation } \\
\text { due to the } \\
\text { implant }\end{array}$ & $\begin{array}{c}1 \text { (1\%) additional } \\
\text { osteosynthesis } \\
\text { due to intra- } \\
\text { articular } \\
\text { fracture, } 2(3 \%) \\
\text { bone graft, } 3 \\
(4 \%) \text { revision } \\
\text { osteosyntheses } \\
\text { due to } \\
\text { overcorrection }\end{array}$ \\
\hline $\begin{array}{l}\text { Gebhard } \\
\text { et al., } 2011\end{array}$ & $\begin{array}{c}\text { p.o. mean leg axis } \\
\text { deviation } 1.5^{\circ}(22(48 \%) \\
\text { patients }<2.5^{\circ}, 39(85 \%) \\
\text { patients }<3.5^{\circ}\end{array}$ & $\begin{array}{c}1(2 \%) \text { severe } \\
\text { bone } \\
\text { complication }\end{array}$ & $\begin{array}{l}2(4 \%) \\
\text { superficial } \\
\text { infections }\end{array}$ & ND & ND \\
\hline $\begin{array}{l}\text { Meidinger } \\
\text { et al. } 2011\end{array}$ & $\begin{array}{l}\text { Correction degree } 7.5 \\
(3-15)^{\circ}\end{array}$ & $\begin{array}{l}10(5 \%) \text { non- } \\
\text { union, fracture } \\
\text { lateral hinge } \\
49(26 \%)\end{array}$ & ND & ND & $\begin{array}{c}10(5 \%) \text { revision } \\
\text { surgery with } \\
\text { debridement } \\
\text { and bone graft } \\
\text { including } 4(2 \%) \\
\text { plate exchanged }\end{array}$ \\
\hline
\end{tabular}

ND means not determined

Table 12. Complications from open-wedge high tibial osteotomy with the TomoFix internal fixator I from various studies. 


\begin{tabular}{|l|c|c|c|}
\hline \multicolumn{1}{|c|}{ Author } & Nerve lesion (n, \%) & $\begin{array}{c}\text { Total knee } \\
\text { arthroplasty }(\mathrm{n}, \%)\end{array}$ & $\begin{array}{c}\text { Implant removal } \\
(\mathrm{n}, \%)\end{array}$ \\
\hline Staubli et al., 2003 & $\begin{array}{c}\text { 10 hyposensitivity of } \\
\text { the saphenous nerve } \\
(11 \%)\end{array}$ & 3 TKA $(3 \%)$ & $\begin{array}{c}37(41 \%) \text { after } 12 \\
(2.5-17) \text { months }\end{array}$ \\
\hline $\begin{array}{l}\text { Galla \& Lobenhoffer, } \\
\text { 2004, Lobenhoffer } \\
\text { et al., 2004 }\end{array}$ & ND & ND & $10(38 \%)$ \\
\hline Takeuchi et al., 2009 & ND & ND & ND \\
\hline Valkering et al., 2009 & ND & ND & ND \\
\hline Zaki \& Rae, 2009 & ND & $1(2 \%)$ & ND \\
\hline Kolb et al., 2009 & ND & $4(8 \%)$ & $68(93 \%)$ \\
\hline Niemeyer et al., 2010 & ND & ND & ND \\
\hline Gebhard et al., 2011 & ND & ND & ND \\
\hline Meidinger et al. 2011 & ND & ND & \\
\hline
\end{tabular}

Table 13. Complications from open-wedge high tibial osteotomy with the TomoFix internal fixator II from various studies.

\section{References}

Aglietti, P.; Buzzi, R.; Vena, L.M.; Baldini, A.; \& Mondaini, A. (2003). High tibial valgus osteotomy for medial gonarthrosis: a 10- to 21-Year study, J Knee Surg, Vo.16, No.1, pp.21-26.

Agneskirchner, J.D.; Hurschler, C.; Stukenborg-Colsman, C.; Imhoff, A.B.; Lobenhoffer, P. (2004). Effect of high tibial flexion osteotomy on cartilage pressure and joint kinematics: a biomechanical study in human cadaveric knees. Winner of the AGADonJoy Award 2004, Arch Orthop Trauma Surg, Vol.124, No.9, pp.575-584.

Agneskirchner, J.D.; Hurschler, C.; Wrann, C.D.; Lobenhoffer, P. (2007). The effects of valgus medial opening wedge high tibial osteotomy on articular cartilage pressure of the knee: a biomechanical study, Arthroscopy, Vol.23, No.8, pp.852-861.

Ahlbäck, S. (1968). Osteoarthrosis of the knee. A radiographic investigation, Acta Radiol Diagn (Stockh), Suppl 277, pp.7-72.

Akamatsu, Y.; Koshino, T.; Saito, T.; \& Wada, J. (1997). Changes in osteosclerosis of the osteoarthritic knee after high tibial osteotomy, Clin Orthop Relat Res, Vol.334, No.1, pp.207-214.

Aydogdu, S.; Cullu, E.; Arac, N.; Varolgunes, N.; \& Sur, H. (2000). Prolonged peroneal nerve dysfunction after high tibial osteotomy: pre- and postoperative electrophysiological study, Knee Surg Sports Traumatol Arthrosc, Vol.8, No.5, pp.305-308.

Babis, G.C.; An, K.N.; Chao, E.Y.; Rand, J.A.; \& Sim, F.H. (2002). Double level osteotomy of the knee: a method to retain joint-line obliquity. Clinical results,. J Bone Joint Surg Am, Vol.84, No.8, pp.1380-1388.

Bae, D.K.; Song, S.J.; \& Yoon, K.H. (2009). Closed-wedge high tibial osteotomy using computer-assisted surgery compared to the conventional technique, J Bone Joint Surg Br, Vol.91, No.9, pp.1164-1171. 
Becker S.T., Warnke P.H., Behrens E., \& Wiltfang, J. (2011). Morbidity after iliac crest bone graft harvesting over an anterior versus posterior approach, J Oral Maxillofac Surg, Vol.69, pp.48-53.

Bhatnagar, T.; \& Jenkyn, T.R. (2010). Internal kinetic changes in the knee due to high tibial osteotomy are well-correlated with change in external adduction moment: an osteoarchritic knee model, J Biomech, Vol.43, No.12, (August 2010), pp. 2261-2266.

Bhattacharyya, T.; Gale, D.; Dewire, P.; Totterman, S.; Gale, M.E.; McLaughlin, S.; Einhorn, T.A.; \& Felson, D.T. (2003). The clinical importance of meniscal tears demonstrated by magnetic imaging in osteoarthritis of the knee, J Bone Joint Surg Am, Vol.85, No.1 pp.4-9.

Billings, A.; Scott, D.F.; Camargo, M.P.; \& Hofmann, A.A. (2000). High tibial osteotomy with a calibrated osteotomy guide, rigid internal fixation, and early motion. Long-term follow-up, J Bone Joint Surg Am, Vol.82, No.1, pp.70-79.

Blackburne, J.S.; \& Peel, T.E. (1977). A new method of measuring patellar height, J Bone Joint Surg Br, Vol.59, No.2, (May 1977), pp.241-242.

Bonin, N.; Ait Si Selmi, T.; Dejour, D.; \& Neyret, P. (2004). [Knee para-articular flexion and extension osteotomies in adults], Orthopäde, Vol.33, No.2, pp.193-200. German.

Bonnin, M.; \& Chambat, P. (2004). [Current status of valgus angle, tibial head closing wedge osteotomy in media gonarthrosis]. Orthopäde, Vol.33, No.2, (February 2004), pp. 135-142.

Brattstroem, H. (1964). Shape of the intercondylar groove normally and in recurrent dislocation of patella. A clinical and x-ray anatomical investigation, Acta Orthop Scand, Vol.68, Suppl, pp.1-148.

Brinkman, J.M., Lobenhoffer, P.; Agneskirchner, J.D.; Staubli, A.E.; Wymenga, A.B.; \& van Heerwarden. R.J. (2008). Osteotomies around the knee: patient selection, stability of fixation and bone healing in high tibial osteotomies, J Bone Joint Surg Br, Vol.90, No.12, (December 2008), pp.1548-1557.

Brinkman, J.M.; Luites, J.W; Wymenga, A.B.; \& van Heerwarden, R.J. (2010) Early full weight bearing is safe in open-wedge high tibial osteotomy, Acta Orthop, Vol.81, No.2, (April 2010), pp.193-198.

Brown, G.A.; \& Amendola, A. (2000). Radiographic evaluation and preoperative planning for high tibial osteotomies, Oper Techn Sports Med, Vol.8, No.1, pp.2-19.

Cartiaux, O.; Paul, L.; Docquier, P.L.; Raucent, B.; Dombre, E.; \& Banse, X. (2010). Computerassisted and robot-assisted technologies to improve bone-cutting accuracy when integrated with a freehand process using an oscillating saw, J Bone Joint Surg Am, Vol.92, No.11, pp.2076-2082.

Chassaing, V.D.F.; Touzard, R.; Ceccaldi, J.P.; \& Miremad, C. (1995). Étude radiologique du L.C.P. à 90 de flexion, Rev Chir Orthop, Vol.81, pp.35-38.

Caton, J. (1989) [Method of measuring the height of the patella], Acta Orthop Belg, Vol.55, No.3, pp.385-386. French.

Coventry, M.B. (1965) Osteotomy of the upper portion of the tibia for degenerative arthritis of the knee: a preliminary report. J Bone Joint Surg Am, Vol.47, No.5, pp.984-990.

Coventry, M.B. (1969). Stepped staple for upper tibial osteotomy, J Bone Joint Surg Am, Vol.51, No.5, pp.1011.

Coventry, M.B. (1985). Upper tibial osteotomy for osteoarthritis, J Bone Joint Surg Am, Vol.67, No.7, pp.1136-1140. 
Dahl, M.T. (2000). Preoperative planning in deformity correction and limb lengthening surgery, Instr Course Lect, Vol.49, pp.503-509.

Debeyre, J, \& Patte, D. (1962). Intérêt des ostéotomies de correction dans le traitement de certaines gonarthroses avec deviation axiale. Rev Rhum Mal Osteoartic, Vol.29, pp.722-729.

Dejour, H.; Walch, G.; Nove-Josserand, L.; \& Guier, C. (1994). Factors of patellar instability: an anatomic radiographic study, Knee Surg Sports Traumatol Arthosc, Vol.2, No.1, pp.19-26.

Dejour, H.; \& Bonnin, M. (1994). Tibial translation after anterior cruciate ligament rupture. Two radiological tests compared, J Bone Joint Surg Br, Vol.76, No.5, pp.745-749.

Dejour, D.; Bonin, N.; \& Locatelli, E. (2000). Tibial antirecurvatum osteotomies, Oper Techn Sports Med, Vol.8, No.1, pp.67-70.

Dugdale, T.W.; Noyes, F.R.; \& Styer, D. (1992). Preoperative planning for high tibial osteotomy. The effect of lateral tibiofemoral separation and tibiofemoral length, Clin Orthop Relat Res, Vol.274, No.1, pp.248-264.

Engel, G.M.; \& Lippert, F.G. (1981). Valgus tibial osteotomy: avoiding the pitfalls, Clin Orthop Relat Res, Vol.160, pp.137-143.

Englund, M.; Guermazi, A.; Gale, D.; Hunter, D.J.; Aliabadi, P.; Clancy, M.; \& Felson, D.T. (2008). Incidental meniscal findings on knee MRI in middle-aged and elderly persons, N Engl J Med, Vol.359, No.11, (September 2008), pp.1108-1115.

Feller, J.A.; Amis, A.A.; Andrish, J.T.; Arendt, E.A.; Erasmus, P.J.; \& Powers, C.M. (2007). Surgical biomechanics of the patellofemoral joint, Arthroscopy, Vol. 23, No.5, pp.542-553.

Felson, D.T.; McLaughlin, S.; Goggins, J.; LaValley, M.P.; Gale, M.E.; Totterman, S.; Li, W.; Hill, C.; \& Gale, D. (2003). Bone marrow edema and its relation to progression of knee osteoarthritis, Ann Intern Med, Vol.139, No.5 Pt 1, pp.330-336.

Fick, R. (1911). Handbuch der Anatomie und Mechanik der Gelenke, Vol.3, Gustav Fischer, Jena.

Freiling, D.; van Heerwarden, R.; Staubli, A.; \& Lobenhoffer, P. (2010). [The medial closedwedge osteotomy of the distal femur for the treatment of unicompartmental lateral osteoarthritis of the knee], Oper Orthop Traumatol, Vol.22, pp.317-334. German.

Frey, P.; Müller, M.; \& Munzinger, U. (2008). [Closing-wedge high tibial osteotomy with a modified Weber technique], Oper Orthop Traumatol, Vol.20, No.1, pp.75-88. German.

Fujisawa, Y.; Masuhara, K.; \& Shiomi, S. (1979). The effect of high tibial osteotomy on osteoarthritis of the knee, Orthop Clin North Am, Vol.10, pp.585-608.

Gaasbeek, R.D.; Sonneveld, H.; van Heerwaarden, R.J.; Jacobs, W.C.; \& Wymenga, A.B. (2004). Distal tuberosity osteotomy in open wedge high tibial osteotomy can prevent patella infera: a new technique, Knee, Vol.11, pp.457-461.

Galla, M.; \& Lobenhoffer, P. (2004). High tibial open wedge valgus osteotomy stabilized with the TomoFix plate fixator, Operat Orthop Traumatol, Vol.16, No.4, pp.397-416. English, German.

Gebhard, F.; Krettek, C.; Hüfner, T.; Grützner, P.A.; Stöckle, U.; Imhoff, A.B.; Lorenz, S.; Liungqvist, J.; \& Keppler, P. (2011). The AO CSEG. Reliability of computer-assisted surgery as an intraoperative ruler in navigated high tibial osteotomy, Arch Orthop Trauma Surg, Vol.131, pp.297-302. 
Giebel, G.; Tscherne, H.; \& Daiber, M. (1985). [Tibial head osteotomy in the treatment of gonarthrosis, Orthopäde, Vol.14, No.3, pp.144-153. German.

Giffin, J.R.; Stabile, K.J.; Zantop, T.; Vodrin, T.M.; Woo, S.L.; \& Harner, C.D. (2007). Importance of tibial slope for stability of the posterior cruciate ligament deficient knee, Am J Sports Med, Vol.35, No.9, pp.1443-1449.

Grelsamer, R.P.; Bazos, A.N.; \& Proctor, C.S. (1993). Radiographic analysis of patellar tilt, J Bone Joint Surg Br, Vol.75, No.5, (September 1993), pp.822-824.

Hankemeier, S.; Mommsen, P.; Krettek, C.; Jagodzinski, M.; Brand, J.; Meyer, C.; \& Meller, C. (2010). Accuracy of high tibial osteotomy: comparison between open- and closedwedge technique, Knee Surg Sports Traumatol Arthrosc, Vol.18, No.10, pp.13281333.

Hanssen, A.D.; \& Chao, E.Y.S. (1994). High Tibial Osteotomy, In Knee Surgery, Vol. 2, F.H. Fu, C.D. Harner \& K.G. Vince, (Eds.), pp.1121-1134, Williams \& Wilkins, ISBN 0683-03389-1, Baltimore, USA.

Hanssen, A.D. (2001). Osteotomy About the Knee: American Perspective. In Surgery of the knee, J.N. Insall, W.N. Scott, (Eds.), Vol 2, pp. 1447-1464, Churchill Livingstone, ISBN, New York, USA.

Van Heerwarden, R.J.; Wymenga, A.; Freiling, D.; \& Lobenhoffer, P. (2007). Distal medial closed wedge varus femur osteotomy stabilized with the TomoFix plate fixator, Oper Tech Orthop, Vol.17, No.1, pp.12-21.

Heijens, E.; Kornherr, P.; \& Meister, C. (2009). The role of navigation in high tibial osteotomy: a study of 50 patients, Orthopedics, Vol.32, No.10 Suppl, pp.40-43.

Hernigou, P.; Medevielle, D.; Debeyre, J.; \& Goutallier, D. (1987). Proximal tibial osteotomy for osteoarthritis with varus deformity. A ten to thirteen-year follow-up study, J Bone Joint Surg Am, Vol.69, No.3, pp.332-354.

Hofmann, S.; \& Pietsch, M. (2007). [Principles and indications of osteotomies around the knee], Arthroskopie Vol.20, No.4, (November 2007), pp. 270-276.

Hofmann, S.; Lobenhoffer, P.; Staubli, A.; \& Van Heerwarden, P. (2009). [Osteotomies of the knee joint in patients with monocompartimental arthritis, Orthopäde, Vol.38, No.8, pp.755-769; quiz 770. German.

Hohmann, E.; Bryant, A.; \& Imhoff, A.B. (2006). The effect of closed wedge high tibial osteotomy on tibial slope: a radiographic study, Knee Surg Sports Traumatol Arthrosc, Vol.14, No.5, pp.454-459.

Hsu, R.W.; Himeno, S.; Coventry, M.B.; \& Chao, E.Y. (1990). Normal axial alignment of the lower extremity and load-bearing distribution at the knee, Clin Orthop Relat Res, Vol.225, pp.215-227.

Imhoff, A.B.; Linke, R.D.; \& Agneskirchner, J. (2004). [Corrective osteotomy in primary varus, double varus and triple varus knee instability with cruciate ligament replacement], Orthopäde, Vol.33, No.2, pp. 201-207. German.

Insall, J., \& Salvati, E. (1971). Patella position in the normal knee joint, Radiology, Vo.101, No.1, (October 1971), pp.101-104.

Iorio, R.; \& Healy, W.L. (2003). Unicompartmental arthritis of the knee, J Bone Joint Surg Am, Vol.85, No.7, pp.1351-1364. Review.

Ivarsson, I.; Myrnerts, R.; \& Gillquist, J. (1990). High tibial osteotomy for medial osteoarthritis of the knee. A 5 to 7 and 11 year follow-up, J Bone Joint Surg Br, Vol.72, No.2, pp.238-244. 
Jakob, R.P.; \& Jacobi, M. (2004). [Closing wedge osteotomy of the tibial head in the treatment of single compartment arthrosis], Orthopäde, Vol.33, No.2, pp. 143-152. German.

Jacobsen, K. (1976). Stress radiographical measurement of the anteroposterior, medial and alteral stability of the knee joint, Acta Orthop Scand, Vol.47, No.3, pp.334-335.

Jackson, J.P.; \& Waugh, W. (1961). Tibial osteotomy for osteoarthritis of the knee, J Bone Joint Surg Br, Vol.43, No.4, pp.746-751.

Kerkhoffs, G.M.; Rademakers, M.V.; Altena, M.; \& Marti, R.K. (2008). Combined intraarticular and varus opening wedge osteotomy for lateral depression and valgus malunion of the proximal part of the tibia, J Bone Joint Surg Am, Vol.90, No.6, pp.1252-1257.

Kessler, O.C.; Jacob, H.A.; \& Romero, J. (2002). Avoidance of medial cortical fracture in high tibial osteotomy: improved technique, Clin Orthop Relat Res, Vol.395, No.2, pp.180185.

Kettelkamp, D.B.; Wenger, D.R.; Chao, E.Y.; \& Thompson, C. (1976). Results of proximal tibial osteotomy. The effects of tibiofemoral angle, stance-phase flexion-extension, and medial-plateau force, J Bone Joint Surg Am, Vol.58, No.10, pp.952-960.

Kirgis, A.; \& Albrecht, S. (1992). Palsy of the deep peroneal nerve after proximal tibial osteotomy. An anatomical study, J Bone Joint Surg Am, Vol.74, No.8, pp.1180-1185.

Köck, F.X.; Weingärtner, D.; Beckmann, J.; Anders, S.; Schaumburger, J.; Grifka, J.; \& Lüring, C. [Operative treatment of unicompartmental knee arthritis - Results of a Nationwide survey in 2008], Z Orthop Unfall, Vol.149, No.2, (February 2011), pp.153-159. [Article in German].

Kolb, W.; Guhlmann, H.; Windisch, C.; Marx, F.; Kolb, K.; \& Koller, H. (2008). Fixation of distal femoral fractures with the Less Invasive Stabilization System: a minimally invasive treatment with locked fixed-angled screws, J Trauma, Vol.65, No.6, (December 2008), pp.1425-1434.

Kolb, W.; Guhlmann, H.; Windisch, C.; Kolb, K.; Koller, H.; \& Grützner, P. (2009). Openingwedge high tibial osteotomy with a locked low-profile plate, J Bone Joint Surg Am, Vol.91, pp.2581-2588.

Kolb, W.; Guhlmann, H.; Windisch, C.; Koller, H.; Grützner, P.; \& Kolb, K. (2010). Openingwedge high tibial osteotomy with a locked low-profile plate: surgical technique, J Bone Joint Surg Am, Vol.92, Suppl 1, pp.197-207.

Koshino, T.; \& Tsuchiya, K. (1979). The effect of high tibial osteotomy on osteoarthritis of the knee. Clinical and histological observations, Int Orthop, Vol.3, No.1, pp.37-45.

Koshino, T.; Morii, T.; Wada, J.; Saito, H.; Ozawa, N.; \& Noyori, K. (1989). High tibial osteotomy with fixation by a blade plate for medial compartment osteoarthritis of the knee, Orthop Clin North Am, Vol.20, No.2, pp.227-243.

Koshino, T. (2010). Osteotomy around young deformed knees: 38-year super-long-term follow-up to detect osteoarthritis, Int Orthop, Vol.34, No.2, pp.263-269.

Krettek, C.; Schandelmaier, P.; Miclau, T.; \& Tscherne, H. (1997). Minimally invasive percutaneous plate osteosynthesis (MIPPO) using DCS in proximal and distal femoral fractures, Injury, Vol.28, (Suppl 1), pp.S-A20-30.

Lichte, P.; Kobbe, P.; Lörken, M.; \& Pape, H.C. (2010). [Planning of corrective osteotomies of the lower limb], Unfallchirurg, Vol.113, No.7, pp. 573-583, quiz 584. German. 
Lind, M.; McClelland, J.; Wittwer, J.E.; Withehead, T.S.; Feller, J.A.; \& Webster, K.E. (2011). Gait analysis of walking before and after medial opening wedge high tibial osteotomy. Knee Surg Sports Traumatol Arthrosc, Apr 12, [Epub ahead of print].

Liodakis, E.; Kenawey, M.; Liodaki, E.; Mommsen, P.; Krettek, C.; \& Hankemeier, S. (2010). The axis-board: an alternative to the cable technique for intraoperative assessment of lower limb alignment, Technol Health Care, Vol.18, pp.165-171.

Langenbeck, B. (1854). Die subkutane Osteotomie, Dtsch Klin, Vol.6, pp.327-330.

Lerat, J.L.; Moyen, B.; Garin, C.; Mandrino, A.; Besse, J.L.; \& Brunet-Guedi, E. (1993). [Anterior laxitiy and internal arthritis of the knee. Results of the reconstruction of the anterior cruciate ligament associated with tibial osteotomy], Rev Chir Orthop App Mot, Vol.79, No.5, pp.365-374.

Levigne, C. ; \& Bonnin, M. (1991). Ostéotomie tibiale de valgisation pour AFTI, Journées Lyonnaises de Chirurgie du Genou, Lyon.

Louisia, S.; Siebold, R.; Canty, J.; \& Bartlett, R.J. (2005). Assessment of posterior stability in total knee replacement by stress radiographs: prospective comparison of two different types of mobile bearing implants, Knee Surg Sports Traumatol Arthrosc, Vol.13, No.6, pp.476-482.

Luites, J.W.; Brinkman, J.M.; Wymenga, A.B.; \& van Heerwarden, R.J. (2009). Fixation stability of opening-versus closing-wedge high tibial osteotomy: a randomised clinical trial using radiostereometry, J Bone Joint Surg Br, Vol. 91, No.11, (November 2009), pp. 1459-1465.

Lo, W.N.; Cheung, K.W.; Yung, S.H.; \& Chiu, K.H. (2009). Arthroscopy-assisted computer navigation in high tibial osteotomy for varus knee deformity, J Orthop Surg (Hong Kong), Vol.17, No.1, pp.51-55.

Lobenhoffer, P.; De Simoni, C.; \& Staubli, A.E. (2002). Open-wedge high tibial osteotomy with rigid plate fixation, Tech Knee Surg, Vol.1, pp.93-105.

Lobenhoffer, P.; Agneskirchner, J.; \& Zoch, W. (2004). [Open valgus alignment osteotomy of the proximal tibia with fixation by medial plate fixator], Orthopäde, Vol.33, No.2, pp.153-160.

Lützner, J.; Gross, A.F.; Günther, K.P.; \& Kirschner, S. (2010). Precision of navigated and conventional open-wedge high tibial osteotomy in a cadaver study, Eur J Med Res, Vol.15, pp.117-120.

Maquet, P. (1976). Valgus osteotomy for osteoarthritis of the knee, Clin Orthop Relat Res, Vol.120, pp.143-148.

Marti, C.B.; Gautier, E.; Wachtl, S.W.; \& Jakob, R.P. (2004). Accuracy of frontal and sagittal plane correction in open-wedge high tibial osteotomy, Arthroscopy, Vol.20, No.4, pp.366-372. Review.

Mast, J.W.; Jakob, R. \& Ganz, R. (1989). Planning and Reduction Techniques in Fracture Surgery, Springer, Berlin, Germany.

http://www.medical.siemens.com/webapp/wcs/stores/servlet/ProductDisplay q_catalogId e_-3 a_catTree e_100010,1007665,12760,1032265 a_langId e_3 a_productId e_202741 a_storeId e_10001.htm

Meidinger, G.; Imhoff, A.B.; Paul, J.; Kirchhoff, C.; Sauerschnig, M.; \& Hinterwimmer, S. (2011). May smokers and overweight patients be treated with medial open-wedge HTO? Risk factors for non-union, Knee Surg Sports Traumatol, Vol.19, No.3, pp.333-339. 
Merchant, A.C.; Mercer, R.L.; Jacobsen, R.H.; \& Cool, C.R. (1974). Roentgenographic analysis of patellofemoral congruence, J Bone Joint Surg Am, Vol.56, No.7, pp.1391-1396.

Merian, M.; Schäfer, D.; \& Hintermann, B. (2005) Proximal tibial valgus osteotomy with callus distraction. Oper Orthop Traumatol, Vol.17, No.3, pp.313-325.

Miniaci, A.; Ballmer, F.T.; Ballmer, P.M.; \& Jakob, R.P. (1989). Proximal tibial osteotomy. A new fixation device, Clin Orthop Relat Res, Vol.246, pp.250-259.

Moreland, J.R.; Bassett, L.W.; \& Hanker, G.J. (1987). Radiographic analysis of the axial alignment of the lower extremity, J Bone Joint Surg Am, Vol.69, No.5, pp.745-749.

Müller, M.; \& Strecker, W. (2008). Arthroscopy prior to osteotomy around the knee? Arch Orthop Trauma Surg, Vol.128, No.11, pp.1217-1221.

Müller, W. (2001). Osteotomies around the knee. Instructional Courses, EFFORT, pp.34-39.

Myrnerts, R. (1980). Failure of the correction of varus deformity obtained by high tibial osteotomy, Acta Orthop Scand, Vol.51, No.3, pp.569-573.

Nagi, O.N.; Kumar, S.; Aggarwal, S. (2007). Combined lateral closing and medial openingwedge high tibial osteotomy, J Bone Joint Surg Am, Vol.89, No.3, pp.542-549.

Nelissen, E.M.; van Langelaan, E.J.; \& Nelissen, R.G. (2010) Stability of medial opening wedge high tibial osteotomy: a failure analysis, Int Orthop, Vol.34, No.2, pp.217223.

Niemeyer, P.; Schmal, H.; Hauschild, O.; von Heyden, J.; Südkamp, N.P.; \& Köstler, W. (2010). Open-wedge osteotomy using an internal plate fixator in patients with medial-compartment gonarthritis and varus malalignment: 3-year results with regard to preoperative arthroscopic and radiographic findings, Arthroscopy, Vol. 26, No.12 (December 2010), pp.1607-1616.

Noyes, F.R.; Barber, S.D. \& Simon, R. (1993). High tibial osteotomy and ligament reconstruction in varus angulated, anterior cruciate ligament-deficient knees. A two- to seven-year follow-up study, Am J Sports Med, Vol.21, No.1, Jan-Feb, pp.212.

Noyes, F.R.; \& Simon, R. (1994). The role of high tibial osteotomy in the anterior cruciate ligament-deficient knee with varus alignment. In Orthopaedic Sports Medicine, Principles and Practice, J.C. DeLee, D. Drez, (Eds.), pp.1401-1443, W.B. Saunders, ISBN 0721628346, Philadelphia, USA.

Noyes, F.R.; Barber-Westin, S.D.; \& Hewett, T.E. (2000). High tibial osteotomy and ligament reconstruction for varus angulated anterior cruciate ligament-deficient knees, Am J Sports Med, Vol.28, No.3, pp.282-296.

Odenbring, S.; Egund, N.; Lindstrand, A.; Lohmander, L.S.; \& Willén, H. (1992). Cartilage regeneration after proximal tibial osteotomy for medial gonarthrosis. An arthroscopic, roentgenographic, and histologic study, Clin Orthop Relat Res, Vol.277, No.4, pp.210-216.

Outerbridge, R.E. (1961). The etiology of chondromalacia patellae, J Bone Joint Surg Br, Vol.43, No.4, pp.752-757.

Paley, D.; \& Tetsworth, K. (1992). Mechanical axis deviation of the lower limbs. Preoperative planning of multiapical frontal plane angular and bowing deformities of the femur and tibia, Clin Orthop Relat Res, Vol.280, No.7, pp.65-71.

Paley, D.; Herzenberg, J.E.; Tetsworth, K; McKie, J.; \& Bhave, A. (1994). Deformity planning for frontal and sagittal plane corrective osteotomies, Orthop Clin North Am, Vol.25, pp.483-498. 
Pape, D.; Seil, R.; Adam, F.; Rupp, S.; Kohn, D.; \& Lobenhoffer, P. (2004). [Imaging and preoperative planning of osteotomy of tibial head osteotomy], Orthopäde, Vol.33, No.2, pp.122-134. German.

Pape, D.; Adam, F.; Rupp, S.; Seil, R.; \& Kohn, D. (2004). [Stability, bone healing and loss of correction after valgus realignment of the tibial head. A roentgen stereometry analysis], Orthopäde, Vol.33, No.2, pp.208-217. German.

Pape, D.; Lorbach, O.; \& Steimer, O. (2007). Analyse der Deformität und präoperative Planung einer knienahen Osteotomie, Arthroskopie, Vol.20, No.4, pp.277-290. [German].

Perusi, M.; Baietta, D.; \& Pizzoli, A. (1994). [Surgical correction of osteoarthritic genu varum by the heimcallotasis technique], Rev Chir Orthop Raparatrice Appar Mot, Vol.80, No.8, pp.739-743. French.

Poignard, A.; Flouzat Lachaniette, C.H.; \& Amzallag, J P. (2010) Revisiting high tibial osteotomy: fifty years of experience with the opening-wedge technique, J Bone Joint Surg Am, Vol.92, Suppl 2, pp.187-195.

Poilvache, P. (2001). Osteotomy for the Arthritic Knee: A European Perspective. In Surgery of the Knee, Vol. 2, J.N. Insall, W.N. Scott, (Eds.), pp.1465-1505, Churchill Livingstone, ISBN 0-443-06545-4, New York, USA.

Prodomos, C.C.; Andriacchi, T.P.; \& Galante, J.O. (1985). A relationship between gait and clinical changes following high tibial osteotomy. J Bone Joint Surg Am, Vol.67, No.8, pp. 1188-1194.

Puddu, G.; Gianni, E.; Chambat, P.; \& De Paulis, F. (2000). The axial view in evaluating tibial translation in cases of insuffiency of the posterior cruciate ligament, Arthroscopy, Vol.16, No.2, pp.217-220.

Rand, J.A.; \& Neyret, P. (2005). ISAKOS meeting on management of osteoarthritis of the knee prior to total knee arthroplasty. ISAKOS, pp.1-8, Hollywood, Florida, USA.

Rodner, C.M.; Adams, D.J.; Diaz-Doran, V.; Tate, J.P.; Santangelo, S.A.; Mazzocco, A.D.; \& Arcieno, R.A. (2006). Medial opening wedge osteotomy and the sagittal plane: the effect of increasing tibial slope on tibiofemoral pressure, Am J Sports Med, Vol.34, No.9, pp.1431-1441.

Rosenberg, T.D.; Paulos, L.E.; Parker, R.D.; Coward, D.B.; \& Scott, S.M. (1988). The fortyfive-degree posteroanterior flexion weight-bearing radiograph of the knee, J Bone Joint Surg Am, Vol.70, No.10, pp.1479-1483.

Savarese, E.; Bisicchia, S.; Romeo, R.; \& Amendola, A. (2011). Role of high tibial osteotomy in chronic injuries of posterior cruciate ligament and posterolateral corner, J Orthop Traumatol, Vol.12, No.1, pp.1-17.

Seitlinger, G.; Scheurecker, G.; Högler, R.; Kramer, J.; \& Hofmann, S. (2010). Bildgebende Diagnostik des Patellofemoralgelenks, Arthroskopie, Vol.23, pp.176-183.

Seitlinger, G.; Beitzel, K.; Scheurecker, G.; Imhoff, A.; \& Hofmann, S. (2011). [The painful patellofemoral joint. Biomechanics, diagnosis and therapy], Orthopäde, Vol.40, No.4, pp.353-368; quiz 369-370. German.

Shaw, J.A.; Dungy, D.S.; \& Arsht, S.S. (2004). Recurrent varus angulation after high tibial osteotomy: an anatomic analysis, Clin Orthop Relat Res, Vol.420, pp.205-212.

Smith, T.O.; Sexton, D.; Mitchell, P.; \& Hing, C.B. (2010). Opening- or closing-wedge high tibial osteotomy: A meta-analysis of clinical and radiological outcomes. Knee, Oct 28, [Epub ahead of print]. 
Song, E.K.; Seon, J.K.; Park, S.J.; \& Jeong, M.S. (2010). The complications of high tibial osteotomy: closing - versus opening-wedge methods, J Bone Joint Surg Br, Vol.92, No.9, pp. 1245-1252.

Stäubli, H.U.; \& Jakob, R.P. (1990). Posterior instability of the knee near extension. A clinical and stress radiographic analysis of acute injuries of the posterior cruciate ligament, J Bone Joint Surg Br, Vol.72, No.2, pp.225-230.

Staubli, A.E.; De Simoni, C.; Babst, R.; \& Lobenhoffer, P. (2003). TomoFix: a new LCPconcept for open wedge osteotomy of the medial proximal tibia-early results in 92 cases, Injury, Vol.34, Suppl 2, pp.B55-62.

Staubli, A.E.; \& Jacob, H.A. (2010). Evolution of open-wedge high-tibial osteotomy: experience with a special angular stable device for internal fixation without interposition material, Int Orthop, Vol.34, No.2, pp.167-172.

Stoffel, K.; Stachowiak, G.; \& Kuster, M. (2004). Open wedge high tibial osteotomy: a biomechanical investigation of the modified Arthrex Osteotomy Plate (Puddu Plate) and the TomoFix Plate, Clin Biomech, Vol.19, No.9, pp.944-950.

Strecker, W.; Dickschas, J.; Harrer, J.; \& Müller, M. (2009). [Arthroscopy prior to osteotomy in cases of unicondylar osteoarthritis], Orthopäde, Vol.38, No.3, pp.263-268. German.

Strobel, M.J.; Weiler, A.; Schulz, M.S.; Russe, K.; \& Eichhorn, H.J. (2002). Fixed posterior subluxation in posterior cruciate ligament-deficient knees: diagnosis and treatment of a new clinical sign, Am J Sports Med, Vol. 30, No.1, pp.32-38.

Takahashi, S.; Tomihisa, K.; \& Saito, T. (2002-2003). Decrease of osteosclerosis in subcondral bone of medial compartmental osteoarthritic knee seven to nineteen years after high tibial valgus osteotomy, Bull Hosp Jt Dis, Vol.61, No.1-2, pp.58-62.

Takeuchi, R.; Ishikawa, H.; Aratake, M.; Bito, H.; Kumagai, K.; Akamatsu, Y.; \& Saito, T. (2009). Medial opening wedge high tibial osteotomy with early full weight bearing, Arthroscopy, Vol.25, No.1, pp.46-53.

Terauchi, M.; Shirakura, K.; Katayama, M.; Higuchi, H.; Takagishi, K.; \& Kimura, M. (2002). Varus inclination of the distal femur and high tibial osteotomy, J Bone Joint Surg Br, Vol.84, No.2, pp.223-226.

Tunggal, J.A.; Higgins, G.A.; \& Waddell, J.P. (2010). Complications of closing wedge high tibial osteotomy, Int Orthop, Vol.34, No.2, pp.255-261.

Urch, S.E.; Tritle, B.A.; Shelbourne, K.D.; \& Gray, T. (2009). Axial linear patellar displacement: a new measurement of patellofemoral congruence, Am J Sports Med, Vol.37, No.5, (May 2009), pp.970-973.

Valkering, K.P.; van den Bekerom, M.P.; Kappelhoff, F.M.; \& Albers, G.H. (2009). Complications after medial opening wedge high tibial osteotomy, J Knee Surg, Vol.22, No.3, pp.218-225.

Weber, B.G., \& Wörsdorfer, O. (1980). Zuggurtungsosteosynthese bei Tibiakopfosteotomie, Z Orthop, Vol.118, pp.637.

Wagner M.; \& Frigg, R. (2006). AO Manual of Fracture Management. Internal Fixators. Concepts and Cases Using LCP and LISS, Thieme, ISBN-10; 3-13-1435551-8, New York, USA.

Wang, J.H.; Bae, J.H.; Lim, H.C.; Shon, W.Y.; Kim, C.W.; \& Cho, J.W. (2009). Medial open wedge high tibial osteotomy: the effect of the cortical hinge on posterior tibial slope, Am J Sports Med, Vol.37, No.12, pp.2411-2418. 
Watanabe, K.; Tsuchiya, H.; Sakurakichi, K.; Matsubara, H.; \& Tomita, K. (2008). Acute correction using focal dome osteotomy for deformity about knee joint, Arch Orthop Trauma Surg, Vol.128, No.12, pp.1373-1378.

Weale, A.E.; Lee, A.S.; \& MacEachern, A.G. (2001). High tibial osteotomy using a dynamic external fixator, Clin Orthop Relat Res, Vol.382, pp.154-167.

Windsor, R.E.; Insall, J.N.; \& Vince, K.G. (1988). Technical considerations of total knee arthroplasty after proximal tibial osteotomy, J Bone Joint Surg Am, Vol.70, No.4, pp.547-555.

Wong, K.C.; Kumta, S.M.; Leung, K.S.; Ng, K.W.; Ng, E.W.; Lee, K.S. (2012). Integration of CAD/CAM planning into computer assisted orthopaedic surgery, Comput Aided Surg, Vol.15, No.4-6, pp.65-74.

Yamamoto, Y.; Ishibashi, Y.; Tsuda, E.; Tsukada, H.; Kimura, Y.; \& Toh, S. (2008). Validation of computer-assisted open-wedge high tibial osteotomy using three-dimensional navigation, Orthopedics, Vol.31, No.10 Suppl 1,

pp. pii: orthosupersite.com/view.asp?rID=35551.

Zaki, S.H.; \& Rae, P.J. (2009). High tibial valgus osteotomy using the Tomofix plate medium-term results in young patients, Acta Orthop Belg, Vol.75, No.3, pp.360367. 


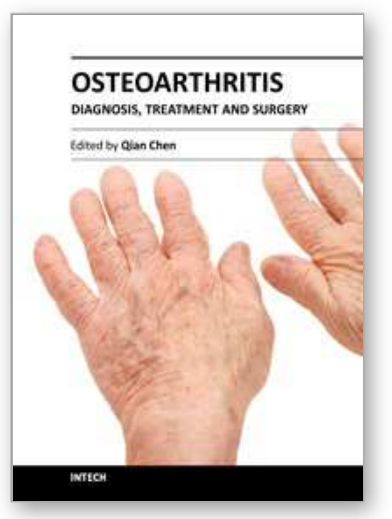

\author{
Osteoarthritis - Diagnosis, Treatment and Surgery \\ Edited by Prof. Qian Chen
}

ISBN 978-953-51-0168-0

Hard cover, 404 pages

Publisher InTech

Published online 02, March, 2012

Published in print edition March, 2012

Osteoarthritis is one of the most debilitating diseases affecting millions of people worldwide. However, there is no FDA approved disease modifying drug specifically for OA. Surgery remains an effective last resort to restore the function of the joints. As the aging populations increase worldwide, the number of OA patients increases dramatically in recent years and is expected to increase in many years to come. This is a book that summarizes recent advance in OA diagnosis, treatment, and surgery. It includes wide ranging topics from the cutting edge gene therapy to alternative medicine. Such multifaceted approaches are necessary to develop novel and effective therapy to cure $O A$ in the future. In this book, different surgical methods are described to restore the function of the joints. In addition, various treatment options are presented, mainly to reduce the pain and enhance the life quality of the OA patients.

\title{
How to reference
}

In order to correctly reference this scholarly work, feel free to copy and paste the following:

Werner Kolb, Hanno Guhlmann, Christoph Windisch and Klaus Kolb (2012). High Tibial Open-Wedge Osteotomy - New Techniques and Early Results, Osteoarthritis - Diagnosis, Treatment and Surgery, Prof. Qian Chen (Ed.), ISBN: 978-953-51-0168-0, InTech, Available from:

http://www.intechopen.com/books/osteoarthritis-diagnosis-treatment-and-surgery/high-tibial-open-wedgeosteotomy

\section{INTECH}

open science | open minds

\section{InTech Europe}

University Campus STeP Ri

Slavka Krautzeka 83/A

51000 Rijeka, Croatia

Phone: +385 (51) 770447

Fax: +385 (51) 686166

www.intechopen.com

\section{InTech China}

Unit 405, Office Block, Hotel Equatorial Shanghai

No.65, Yan An Road (West), Shanghai, 200040, China

中国上海市延安西路65号上海国际贵都大饭店办公楼 405 单元

Phone: +86-21-62489820

Fax: $+86-21-62489821$ 
(C) 2012 The Author(s). Licensee IntechOpen. This is an open access article distributed under the terms of the Creative Commons Attribution 3.0 License, which permits unrestricted use, distribution, and reproduction in any medium, provided the original work is properly cited. 